\title{
PÉTERfFy Gergely
}

\section{Közlekedés és Néphadsereg. A 150. közlekedési múszaki dandár részvétele a közlekedési infrastruktúra fejlesztésében, 1964-1977.}

\author{
Transportation and the Hungarian People's Army. The $150^{\text {th }}$ \\ Transportation Engineering Brigade's Participation in Developing \\ the Infrastructure
}

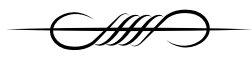

\begin{abstract}
In the Warsaw Pact member states mandatory military service enlistment of people created a serious financial burden, while depriving the economy of a large chunk of its labour force. To resolve this dilemma, in 1964 two engineering brigades were set up in the Hungarian People's Army. Following a brief basic military training, these brigades supplied the labour force for national economy projects, but also created an opportunity to acquire income for the military budget. The $150^{\text {th }}$ Transportation Engineering Brigade was created to support transport projects. Soldiers took part in Hungary's all key, still operating road and railway developments. Also, thanks to acquiring specialised knowledge, they got a chance to work for transport services following their military discharge.
\end{abstract}

\section{KEYWORDS}

army, cold war, highway, infantry, modernisation, motorisation, railways 
DOI 10.14232/belv.2021.2.4

https://doi.org/10.14232/belv.2021.2.4

Cikkre való hivatkozás / How to cite this article:

Péterffy Gergely (2021): Közlekedés és Néphadsereg. A 150. közlekedési müszaki dandár részvétele a közlekedési infrastruktúra fejlesztésében, 1964-1977. Belvedere Meridionale 33. évf.

2. sz. $72-111 . \mathrm{pp}$

ISSN 1419-0222 (print)

ISSN 2064-5929 (online, pdf)

(Creative Commons) Nevezd meg! - Így add tovább! 4.0 (CC BY-SA 4.0)

(Creative Commons) Attribution-ShareAlike 4.0 International (CC BY-SA 4.0)

www.belvedere-meridionale.hu

A szocializmus alatt a közlekedés soha nem kapta meg azt a politikai-gazdasági támogatást, amire szüksége lett volna ahhoz, hogy a ráosztott feladatokat fennakadások nélkül elláthassa. Lehetett nagy szavakat mondani, terveket készíteni, de amikor a tervek megvalósításához értek, hamar elfogyott a lelkesedés, a források meg még annál is gyorsabban. Hasonló volt a helyzet az 1964-ben felállított két műszaki magasabbegységgel, a 150. közlekedési műszaki dandárral és a 160. általános müszaki dandárral. Lehetett rájuk hivatkozni; lám a katonák építenek, termelnek is, nem felesleges pénzkidobás a néphadsereg fenntartása. A hadsereg történetével foglalkozó professzionalista és amatör történészek azonban nem tudnak mit kezdeni ezen alakulatok történetével, emlékével. A rendszerváltás előtt készült néhány kézirat - jellemzően az alakulatok nyugállományú tisztjeinek tollából - a néphadsereg civil gazdaságot segítő tevékenységeiről, de ezek nem kerültek publikálásra. ${ }^{1} 1989$ után megjelent munkák egy-két mondattal és egy rövid felsorolással emlékeznek meg az új kiképzési rendszerủ alakulatokról, ${ }^{2}$ kivéve Fodor Kálmán 2008-as tanulmányát, ahol részletes adatok olvashatók a két dandár teljesítményéről. ${ }^{3}$

Sajnos a Hadtörténeti levéltárban örzött iratok hiányosak, egyes évek dokumentumai nem kerültek be minden zászlóaljtól, mint például a 154. közúti, a 156. és 158. vasúti zászlóaljaké - a 157. vonalépítő zászlóaljtól pedig semmilyen forrás nem maradt fenn. Nehezítette az iratok feldolgozását, hogy nem alakult ki egy zászlóaljnál sem egységes parancsrögzítési rendszer (vagy nem tartották be az erre vonatkozó elöírásokat). Ugyanazon zászlóaljparancsnok két-három éven belül teljesen más struktúrájú napi parancsokat, utasításokat adott ki. Emiatt fordul elö többször is, hogy az egyik évben a szolgálati használatra kiadott iratok között, a másik évben pedig általános napi parancsok között található a zászlóaljak éves munkaterve. Az előbbiben az alakulat vezetőállományára - hivatásos és továbbszolgáló állomány, valamint

A Zrínyi Miklós Katonai Akadémián az 1980-as években készült tudományos igénnyel megírt publikáció a néphadsereg különböző alaprendeltetéstől eltérő feladatainak vázlatos összegzésére „,A Magyar Néphadsereg története 1945-1980" címü tanulmánykötet egyik fejezeteként, ami viszont a rendszerváltás miatt már nem látott napvilágot.

2 Szani 1999.; Helgert - Vass 2006.

3 Fodor 2008. 
polgári alkalmazottak - vonatkozó intézkedések és a sorállomány századokba való beosztása találhatók meg. Az utóbbiban az adott alakulat mindennapi életét befolyásoló parancsok (sorállományúak fenyítései és dicséretei, a teljes állományra vonatkozó egészségügyi szabadságolások, útbaindítások, stb) - ezekből értelemszerüen jóval több készült el adott évben, mint a szolgálati használatúak közül. Nem egyszer előfordul, hogy egyáltalán nem maradt fenn forrás éves munkatervre, néha még a dandár anyagai között sem. Ilyen esetekben kénytelen voltam más forrásokkal összevetni az úgynevezett „útbaindítási parancsokat” és így következtetni az alegység munkahelyeire. Rendkívül érdekesek a baleseti jegyzőkönyvek, amik rávilágítanak a konkrét munkavégzésre, színessé, emberközelivé téve a katonák hétköznapi életét. Sajnálatos módon csak az 1972-73-as év jegyzőkönyvei maradtak fenn a dandár összes alegységére vonatkozóan. A hiányzó láncszemek kiegészítésére a MÁV Archívumában őrzött iratok, valamint az „Autó-Motor”, „Néphadsereg”és „Vasút” c. periodikák nyújtottak segítséget.

\section{KÖZLEKEDÉS SZEREPE A NÉPGAZDASÁGBAN}

A szocialista gazdasági rendszer sokban hasonlított a politikai berendezkedéshez. Egy központi szervezetből próbálták az ország gazdasági életét irányítani felülről megszabott teljesítményi mutatókkal, beruházásokkal, a helyi kezdeményezések, lokális igények csak korlátozott módon érvényesülhettek. Magyarországon az Országos Tervhivatal határozta meg az ország termelöágazatainak termelési és fogyasztási mutatóit több éves ciklusokkal számolva, lásd a három- és ötéves terveket. A tervidőszakokat lebontották éves szintekre, majd az egyes minisztériumok tovább bontották azokat az irányításuk alá tartozó üzemekre, vállalatokra. A minden évben meghirdetett munkaversenyek miatt ezeket a tervszámokat igyekeztek túlteljesíteni, függetlenül attól, hogy volt-e valós vásárlói igény az adott termékre vagy sem. Az ideológiai kényszer szülte mennyiségi szemlélet szükségszerüen a minőség rovására ment, és bár történtek kísérletek a minőség előtérbe helyezésére, a politikai adottságok miatt erre nem volt valós esély.

A tervutasításos gazdasági rendszerek egyik sajátossága volt az üzemek, vállalatok év végi csúcsra járatása. Az államosítás miatt csak monopolizált állami cégek voltak a „piacon”. Az őszi-téli időszak a mezőgazdasági betakarítás miatt egyébként is rendkívül hajtós volt a közlekedés számára, hiszen a friss gyümölcsöt, zöldséget a lehető leggyorsabban kellett továbbítani a célállomásra. A szállítási igényeket jelentősen megemelte azonban, hogy az egyes üzemek, behozandó az év eleji lemaradásukat, ősztől fokozták a termelésüket. ${ }^{4}$ Hogy termékeiket el tudják időben szállítani a megrendelőnek, számítva más üzemek teherszállítási kapacitás előfoglalására, a szükségesnél több vagont, ${ }^{5}$ teherautót igényeltek, jóval korábban a szükséges időnél, mivel a szolgáltató vállalat általában csak késve tudta kiállítani a kért jármüveket, amelyek megrakodását általában emberi erővel végezték, a rakodás gépesítése nagyon lassan haladt előre. A fentiek miatt

4 Nyers Rezső az MSZMP KB 1963 október 18-i kibővített ülésén mondta a következőt, miközben a közlekedés aktuális helyzetéről és az őszi forgalmi csúcsról tartott beszámolót „Időszerű gazdasági feladatok” címmel: „A közlekedésben az egész népgazdaság elmaradását kell behozni.” MNL OL M-KS 288. f. 4. á. 64. őe. https://adatbazisokonline.hu/pdfview2?file=static/documents/mszmp_mdp/HU_MNL_OL_M-KS_288_04_00640.pdf\#search=\&page=2 Hozzáférés: 2021.07.13.

A vállalatok egyre több vagont halmoztak fel, akár háromszoros-négyszeres vagonmennyiséget is rendeltek, hogy mindenképpen legyen vasúti kocsijuk a szállításokra. A vasúti kocsiálláspénz 1964 első 9 hónapjában 160 millió forintot tett ki. 
tehát minden év végén kapacitáshiány jelentkezett a túlfütött kereslet miatt. Tovább nehezítette a helyzetet, hogy a pályák és a vasúti kocsik állapota az elmaradt korszerüsítések és az egyre növekvő forgalom miatt egyre gyakrabban szorultak javítási munkákra, ami tovább lassította a forgalmat, a a teherautók többségének teherbírása pedig a 3-5 tonnás közepes teherbírású kategóriába tartozott. ${ }^{6}$ Válságos időszakokban a MÁV és a Központi Szállítási Tanács - ez a szerv igyekezett összehangolni az egyes vállalatok és állami szervek szállítási igényeit - igyekezett korlátozni a szállítási keresletet, de ez csak még jobban felverte a keresletet. A csúcsidőszak lefutása utáni periódusban a vállalatok kipihenték az előző hónapok feszített ütemét, emiatt jelentősen elmaradtak a tervhez képesti szállításokkal, ami tönkretette volna a fuvarozók, elsősorban a vasút éves tervét, ezért a fuvarozó összejátszott a fuvaroztatóval. A beruházások visszafogása idején viszont a vállalatok tartalékolni próbáltak, ilyenkor nem nagyon esett vissza a fuvarozási kereslet. Egy-egy vállalat, szövetkezet tavasszal több vagont rendelt meg a vasúttól, mint amennyire szüksége lett volna, cserébe a MÁV az öszi csúcsidőben ezeket a vállalatokat elöre sorolta a szállitási listán.

A legsúlyosabb szállítási válságok 1962-64, 1973-74 és 1978-80 évek őszén és telén alakultak ki, a nemzetközi forgalmat bonyolító vasútvonalak állomásain feltorlódtak a tehervonatok, így a személyvonatok közlekedtetése is rendkívüli erőfeszítéseket kívánt. 1962-1964 között kulminálódó szállítási válság következtében Kossa Istvánnak fel kellett állnia a bársonyszékből, az új közlekedési- és postaügyi miniszter 1963. december 7-től Csanádi György, a MÁV korábbi vezérigazgatója lett.

Közlekedés előbb felsorolt problémái az egész szocialista tömbre vonatkoztak. Az egyes országok fuvarozási válságai természetesen kihatottak a szomszédos országokra, és az infrastruktúrától függően növelhették a térség közlekedési problémáit.

A problémákat az operatív apparátus elsősorban a kevés és elhasználódott jármüállagban látta, ezért járművek vásárlását favorizálta. Mivel a dízelesítés lassan haladt, a szállítási válság pedig minden korábbinál aggasztóbb méreteket öltött, ezért a MÁV 12 darab jóvátételként gyártott 424-es gőzmozdonyt vásárolt vissza a Szovjetuniótól 1962 szeptemberében. ${ }^{7}$ A szállítási gondok azonban nem enyhültek, ezért a kormány további használt gőzmozdony beszerzését engedélyezte a Szovjetuniótól. Száz darab második világháborús, német gyártású hadimozdony került így a MÁV-hoz, amelyek becsülettel végigszolgálták a magyar gőzös korszakot. Ezeket a gépeket a vasutasok némi iróniával „Hruscsov-dízelnek” nevezték, utalva a korszerüsítési program lassú menetére. ${ }^{8}$

Az ötéves tervekben rögzített, eleve kevés beruházási források sem valósultak meg mindig. 1955 és 1960 között népgazdasági beruházásokra 138,4 milliárdot, felújításokra 44,1 milliárdot fordítottak. Középtávú tervek szerint szállításra a beruházások $26 \%$-át fordították volna, ehhez képest csak 9,1\% valósult meg, míg a felújításoké 26,8\%-ra csökkent. A közlekedési beruházásokból $46 \%$ jutott a vasútra és 33,5\% a közútra, felújításoknál $64,8 \%$ és $6,8 \%$ volt az arány. 1961 és 1965 között a népgazdasági beruházások összértéke 227,3 milliárd Ft volt, ennek majdnem a negyedét, 22,6\%-ot terveztek a közlekedésre fordítani. Ehhez képest a beruházásokból és beszerzésekböl csak 10,3\%-al, felújítási költségekböl 28,6\%-al részesedett a közlekedés. ${ }^{9}$

\footnotetext{
Major 1984. 68.

7 Frisnyák 2001. 231.; Máthé et. al. 2007. 52-61.

8 Frisnyák 2001. 233.; Máthé et. al. 2007. 62-63. A MÁV-nál az 520 sorozatszámot kapták.

9 Major 1984. 154-155.
} 
A nehézipar fejlesztése elsőbbséget élvezett a többi gazdasági szektor kárára. Különösen az ötvenes években pörgették fel a nehézipari beruházásokat, egy esetleges III. világháborúra való készülődés jegyében. Ez a türelmetlenséggel és dogmatikus merevséggel párosuló iparfejlesztés még az olyan, nyersanyagban gazdagabb országokat is megviselte, mint Lengyelország. Magyarország jóformán csak bauxitból és uránércből rendelkezett számottevő mennyiséggel, kőszénből, vasércből és számos ipari félkész termékből, de még fából is behozatalra szorult az ország. Természetesen a Szovjetunió lett Magyarország legnagyobb külkereskedelmi partnere mind az export, mind az import terén. A magyar-szovjet kereskedelem jellemzően vasúton, a Budapest-Miskolc/Debrecen-Záhony-Lvov útvonalon zajlott. Közúton csak sürgősségi esetekben történt áruszállítás, amikor az áruforgalom volumene már a vasúti közlekedést is megbénította. Mivel a Kölcsönös Gazdasági Segítség Tanácsában (KGST) résztvevő államok közötti áruforgalom cserekereskedelmi jellegű volt, így a Szovjetunióból érkező nyersanyagért, gépipari és műszaki árukért Budapest mezőgazdasági, élelmiszeripari, műszaki és vegyipari cikkekkel egyenlítette ki tartozását. A tagországok közti kereskedelmet úgynevezett klíring rubelben számolták, valódi pénzmozgás nélkül. Magyarország földrajzi elhelyezkedése miatt jelentős részt vállalt a tranzit-forgalomból, aminek a bevétel mellett megvolt az a hátránya, hogy rendkívül sok vonatot kellett leközlekedtetnie a szomszédos országok között. A tranzit-forgalom az 1970-es években vált jelentőssé, közlekedési és gazdasági szinten egyaránt. ${ }^{10}$

Ehhez társult a hatvanas-hetvenes évek fordulóján kezdődő „gépkocsi-bumm”. Amíg 1965ben mindössze 82640 magántulajdonban lévő személyautó szerepelt a statisztikában, öt évvel később 213436, 1975-ben már 550548, vizsgált időszakunk végén pedig 978148 rótta az utakat. ${ }^{11}$ A hatvanas évek státuszszimbólumát jelentő hütőszekrényt, mosógépet és televíziót egy évtized alatt felváltotta a személygépkocsi. Ezzel együtt természetesen a közúti forgalom is emelkedett, mind a buszközlekedés, mind a közúti árufuvarozás. A hatvanas évek közepétől a közúti személyszállítás már több utast szállított el, mint a vasút. Termékekből és fogyasztásból 1974-ben 22474 Ft jutott egy före, ebből 1701 Ft-ot költöttek átlagosan a közlekedésre, vagyis a fogyasztás 7,6\%-át fordították utazásra és napi munkába járásra. 1960-ban ez az arány még csak $4,2 \%$ volt. $^{12}$

A hatalom rátette kezét a gépjárművek értékesítésére is, nem csak ideológiai okokból, hanem gazdasági megfontolások miatt is. A Rákosi-kor önkéntesség álcája alatt elöírt békekölcsön jegyzését felváltotta az önként vállalt autózási adók. Kádár rátapintott a lényegre amikor a következőket mondta: „A személyautó ma olyan, mint a békekölcsön volt az ötvenes években. A kettö között csak az a különbség, hogy a békekölcsönre az emberek szitkozódva adták a pénzt, az autót viszont dalolva fizetik. "13 A gépkocsi birtoklás a relatíve magas árak és adók a kincstári bevételszerzés mellett a lakosság vásárló erejének szabályozását is szolgálta. A Merkurnál az új gépkocsi vételárának 20, 1979-től 50\%-át kellett előre befizetni és a kiválasztott jármü beérkezéséig a fennmaradó részletet törleszteni.

Magyarország a KGST szakosodási megállapodása szerint lemondott a teherautó-gyártásról (a személyautó-gyártás nem is volt), cserébe az Ikarus láthatta el a szocialista blokk

10 Ábrahám 1978. 30; Major 1984. 22-23.

11 Statisztikai évkönyv 1965, 1970, 1975, 1980.

12 Ábrahám 1978. 30.

13 Major 1984. 189. 
országait autóbuszokkal. ${ }^{14}$ Így az ország behozatalra szorult gépkocsiból is. Nem csak a szocialista országok autógyárainak volt azonban korlátozott kapacitása, ${ }^{15}$ de az állam is korlátozta a gyáraktól való megrendeléseket, nehogy felboruljon a külkereskedelmi fizetési mérleg. A magas adóterheket a közútfejlesztésre létrehozott alap feltöltésével indokolták, valójában az alap felett nem a Közlekedési- és Postaügyi Minisztérium (KPM), hanem a Pénzügyminisztérium és az Országos Tervhivatal rendelkezett, így a bevételek jelentős részét nem a közúthálózat fejlesztésére fordították. ${ }^{16} \mathrm{Az}$ autópiac korlátozására általában az infrastruktúra hiányosságait hozták fel indokként, valójában a közúti közlekedésből befolyó összegek messze meghaladták a közútra fordított fejlesztési pénzeket. 1972-ben 8,45 milliárd Ft-ot használtak fel beruházásra, miközben a bevétel 17,72 milliárd volt. 1976ban 16,1 milliárdot fordítottak az úthálózat korszerüsítésére és új beruházásokra a 24,35 milliárdos bevételből, 1980-ban pedig 13,5 milliárdot a befolyó 29,6 milliárd forintból. A gépkocsiforgalmazásból származó haszon 1972-ben 1,9 milliárdot, 1976-ban 1 milliárdot, 1980-ban 3,6 milliárd Ft-ot jelentett az államkasszának. ${ }^{17}$

A szállítási nehézségeket fokozta a hatvanas évektől meginduló iparszéttelepítési program. 1959-ben fogalmazták meg az új területi fejlesztési politikát, amelyben az ipar decentralizálásáról és szegényebb térségekbe való telepítéséről döntöttek. Az elképzelés alapja az volt, hogy az ipar telepítésével csökkenteni lehet a területi egyenlőtlenségeket. Elsősorban feldolgozóipari üzemeket helyeztek vidékre, hogy az agráriumból elvándorló embereket a környéken tudják alkalmazni, és ne az amúgy is lakásgondokkal küszködő fővárosban próbáljanak szerencsét. Szabolcsban négyszeresére, Békés, Bács-Kiskun és Somogy megyékben háromszorosára nőtt az iparban foglalkoztatottak száma az 1960-70-es években. Az infrastruktúra fejlesztése viszont nem tartott lépést az iparosítással, komoly lemaradásban volt mind a vasúti, mind a közúti közlekedés, a hírközlési hálózat állapota egyenesen katasztrofálisnak bizonyult. ${ }^{18} \mathrm{~A}$ kisebb termelőegységeket ráadásul az ipartelepítési politika miatt az iparban szegényebb területeken építették fel, amelyek nem csak az anyavállalattól, hanem a gazdasági centrumoktól is távolabb helyezkedtek el. Először a termékeknek a központba kellett eljutniuk, onnan szállították tovább a területi egységhez, így a termék vagy félkész áru akár kétszer is megtehette ugyanazt az utat - jelentős plusz szállítási kapacitást lekötve - majd ezután a telephelyről továbbítani kellett az árut a megrendelöhöz. ${ }^{19}$ A hetvenes években tovább folytatódott a vállalatok és termelöszövetkezetek összevonása, így fokozódott a központ és telephely közötti szállítási igény. Nőtt a vállalatok nyersanyag és import igénye is a tervmutatók növelésével. A nagy tömegủ szállításokat még mindig föleg a vasút végezte. Az import-szállításokból 54-60\%-kal, az exportból 60-64\%-kal, a

${ }^{14}$ Nem minden ország tartotta be a megállapodást, a csehek tovább gyártották a Karosa buszokat, a románok különutas politikájáról nem is beszélve.

15 A szocialista autógyárak elsőként a nyugati keresletet igyekeztek kielégíteni piacképes típusaikkal, hiszen devizát hozott a gazdaságnak. Csak ezután következtek a szocialista tábor országainak megrendelései, illetve belföldi megrendelések kielégítése. Jó példa erre a Skoda 110R coupé típus, amit elsősorban nyugati piacra gyártottak, ezért szocialista relációban felülárazták a gépkocsit, hogy minél kevesebb megrendelés érkezzen a testvéri országokból, így jórészt csak a nyugati piacra tudtak fokuszálni Mlada Boleslav-ban.

16 Major 1984. 186-189.

17 Major 1984. 305-309.

18 Valuch 2005. 54-55.

19 Major 1984. 99-104. 
tranzitforgalomból 58-60\%-kal részesedett a vasút (a másik jelentős nemzetközi fuvarozó eszköz a hajózás volt). ${ }^{20}$

Új munkahelyek létrehozása, a kollektivizálás, majd az iparszéttelepítési politika következtében rohamosan nőtt a földmüvelést elhagyó, megélhetést a városban kereső ingázók száma, elsősorban naponta utazóké. A napi ingázók abszolút száma az 1980-as évek elejéig nőtt. 1960ban 143 olyan település volt, ahol a lakosok legalább 50\%-a ingázott, tíz évvel később 842-re, 1980-ban már 1820-ra nőtt számuk.Az ingázás jelenségét elősegítette az alacsony személyszállítási díjszabás. Távolsági személyszállítás díjait 1951-ben, a közúti helyi személyszállítás díjait 1966-ban emelték utoljára. 1975-ben az összes utasok 62,6\%-a még a közhasználatú közlekedést választotta, de az utaskilométerek hozzávetőlegesen felét már az egyéni közlekedés bonyolította. Vasúton elszállított utasok száma 1967-ig folyamatosan nőtt, majd a buszhálózat növekedése, a mellékvonalak bezárása és a személyautók számának dinamikus növekedése miatt csökkenésnek indult. ${ }^{21}$

A gazdasági reformmal párhuzamosan, a közlekedésben is több éves előkészítő munka után 1968-ban indítottak el egy reformprogramot, amit Közlekedési koncepció néven fogadott el az országgyülés 1968. október 17-én. Az igazi gazdasági reform nem sikerülhetett, mert az egész tervgazdasági rendszer felszámolásával járt volna, de még ezt a módosított, több lényegi elemétől már korábban megfosztott reform is felszámolásra került, mert Moszkva nem nézte jó szemmel - különösen a Prágai tavasz után - egy, az ideológiai alapelvek megkérdőjelezését lappangva magában hordozó szisztémát. Ami megvalósult a közlekedésben, az is felemás módon sikerült. Bevezették a vállalati gazdálkodás néhány elemét, az infrastruktúrai szolgáltatásokat azonban továbbra is állami monopóliumok végezték.

Továbbra is magas maradt a nyersanyag szükséglet és alacsony energiahatékonysággal dolgoztak az üzemek, az anyagfelhasználás és termelés változatlanul meghaladta a népgazdaság növekedését. A szállítási teljesítmények hullámzása is megmaradt az évi összesítésekben, az 1980-ra tervezett teljesítményi szintet már 1973-74-ben elérte a közlekedés. Az áruszállítási teljesítmény 85\%-kal, a személyszállítás pedig 125\%-kal nőtt. 1968-1980 között a vasúti importszállítások 35,5\%-kal, az exportszállítások 90\%-kal nőttek összességében. A vasúti exportszállítások 30-40\%-a, míg az importé csak 10-20\%-a volt tőkés relációjú. Az import 80-90\%-a a szocialista országokból származott, ezen belül is 50-60\%-kal részesedett a Szovjetunió. Termékszerkezet szerint a népgazdasági import 62\%-át energiahordozók, nyersanyagok és félkész termékek tették ki, ugyanezek aránya az exportban 35\% körül alakult.

\section{KÖZLEKEDÉSPOLITIKAI KONCEPCIÓ}

1956 után egyre nyilvánvalóbbá vált, hogy a közlekedés problémái már nem orvosolhatók extenzív módszerekkel, a rendszer minőségi átalakítása elkerülhetetlenné vált. 1958. február 1112-én tartotta a Magyar Tudományos Akadémia Müszaki Tudományok Osztálya közúti konferenciáját, melyen Csanádi György, a MÁV vezérigazgatója egy új, a közlekedés egészére vonatkozó reform szükségességét fogalmazta meg. A nyugat „,anarchikus” körülmények között

\footnotetext{
20 Major 1984. 252-256.

21 Ábrahám 1978. 40.; Ingázás társadalmi vonatkozásairól lásd: Bőhm 1997.
} 
zajló közúti-vasúti áruszállítási versenye helyett a szocialista rendszer tervszerüségében látta a megoldást a közlekedési nehézségekre. A közlekedéstudományra támaszkodva kell felmérni az ország számára szükséges közlekedési hálózat igényeit, hiszen „,Ettöl várhatjuk, hogy bármiféle elfogultságtól, partikuláris gyakorlattól mentesen számba vegye azokat a bonyolult összefüggéseket felmutató müszaki, forgalmi, gazdasági és egyéb tényezöket, amelyeknek a vasút-gépkocsi problémában és egyáltalán: a közlekedési ágazatok közötti optimális forgalommegoszlásban, feladataik koordinálásában szerepük van. "22 A valódi hatékonyság érdekében a szociális, kulturális, politikai és honvédelmi szempontok figyelembe vételével kell megalkotni az új közlekedéspolitikát. Az egységes közlekedési rendszerben az egyes fuvarozó vállalatok között felosztott feladatok révén remélte a leghatékonyabb megoldást. ${ }^{23}$ Valójában figyelmen kívül hagyta a szocialista rendszerben is meglévő, bújtatott (ellen)érdekeket.A hatékony együttmüködés egyik alapvető előfeltételének tartotta a vasúthálózat racionalizálását, az alacsony forgalmú - és ezáltal veszteséges - vasútvonalak megszüntetését, a fennmaradó vasúti hálózat fejlesztését, valamint a közúthálózat bővítését és a jármüpark korszerüsítését. ${ }^{24}$

Alapvetően hasonló gondolatokat fogalmazott meg az MSZMP PB 1958. május 6-i határozata „a közlekedés fejlesztésének irányára” címmel. A párt irányító testülete hangsúlyozta a közlekedési ágazatok egységes rendszerének fontosságát, és a teljes ágazat fejlesztését. Fejlesztési források hiányában azonban még mindig a vasútnak jutott a meghatározó szerep, ezért a határozat a fövonalak korszerüsítéséről, valamint a villamosítási és dízelesítési programról döntött. Itt is megjelent a körzetesítés, mint a vasút és közút munkamegosztásának ideális eszköze. ${ }^{25}$ A vasútvonalak bezárása is megjelent már a határozatban: „Mindazokat a vasútvonalakat, amelyeknek a fenntartása a csekély forgalom miatt nem gazdaságos, a közúti közlekedés egyidejü fejlesztése mellett meg kell szüntetni, illetve korlátozásokkal, egyszerüsített üzemviteli formában kell fenntartani." A határozat intézkedett még a közúthálózat és jármüállomány fejlesztésére, valamint felkérte az Országos Tervhivatalt, hogy készítsen távlati terveket a közlekedés fejlesztésére. $^{26}$

1964. december 10-i ülésén az MSZMP KB határozata ismét csak a közlekedési hiányosságokról számolt be, ugyanis terven felül kellett jármüveket vásárolni. ${ }^{27}$ Ezután az MSZMP PB 1965. június 8-i ülése foglalkozott mélyebben a közlekedéspolitikával. Kosári József jelentése azonban nem tartalmazott az eddigiekhez képest markáns eltérést a személyszállítási tarifák kivételével. A közlekedés egésze rentábilis volt a népgazdaság számára a személyszállítás kivételével, mert a vasútnál és a hajózásnál megszabott díjak 1951 óta nem változtak, ráadásul

22 Csanádi 1958. 281. Kiemelés az eredetiben.

23 Csanádi 1958. 282.

24 Csanádi 1958. 283-285. 1954-ben a 8025 km-es hálózatból 4200 km adta a teljesítmények 91\%-át

25 Körzetesítés: egyes vasútvonalakon néhány nagyobb állomás kijelölése árufeladó és áruleadó állomásnak ahová és ahonnan gépkocsikkal lehet a teherárut tovább szállítani a vonal többi áruforgalomra berendezett állomás egyidejü megszüntetésével.

26 MSZMP PB 1958 május 6-i határozata. MNL OL. M-KS 288. f. 5. á. 77. őe. https://adatbazisokonline.hu/pdfview2?file=static/documents/mszmp_mdp/HU_MNL_OL_M-KS_288_05_00770.pdf\#search=\&page=1 Hozzáférés: 2021.07.13. Vasútfejlesztés ügyében már e-kkor megjelent a hadsereg, még ha csak közvetett módon is: „,A Politikai Bizottság szükségesnek tartja, hogy a vasúti forgalom megjavitására a Honvédelmi Minisztérium, a honvédelmi igények figyelembevételével megfelelö anyagokat bocsásson a vasút rendelkezésére."

27 Vass 1968. 95. „A közlekedés fejlesztése nem tartott lépést a szállitási követelményekkel, ezért az ötéves terv végrehajtása közben szükségessé vált a fejlesztés gyorsitása." 
kedvezmények széles körét vehették igénybe az emberek. Az előadásban ugyanakkor már megjelent a közlekedési ágazatok szocialista tervszerüséget mellőző versengése.

A hosszú évek óta szorgalmazott reform végül 1968-ban készült el, amit 1968. október 17én fogadott el az országgyülés az új vasúti törvénnyel együtt. ${ }^{28}$ A program elvi újdonsága az volt, hogy hivatalosan is termelő tevékenységnek nyilvánította az áruszállítást. A közlekedési koncepció fő hangsúlya a vasúti és közúti közlekedés viszonyának új alapokra helyezése volt, egy olyan munkamegosztás kidolgozása a két ágazat között, ami hosszú távon megoldja a szállítási problémákat. A koncepció az 1958-as párthatározat alapján a közlekedés népgazdasággal arányos fejlesztését tüzte ki célul. Ehhez a belső arányokat a vasúti mellékvonalak egy részének - mintegy $2000 \mathrm{~km}$ - felszámolásával és a közúti közlekedés fejlesztésével akarták korrigálni. Kevés híján teljesült a kitüzött 2000 km vasútbezárás, 1965-ös 10421 km közforgalmú és korlátozottan közforgalmú vasúthálózat 1980-ra 8162 km-re csökkent. ${ }^{29}$

1. táblázat: Megszüntetett vasútvonalak ${ }^{30}$

\begin{tabular}{|l|c|c|c|}
\hline Év & Keskeny nyomtávú $(\mathrm{km})$ & $\begin{array}{c}\text { Normál nyomtávú } \\
(\mathrm{km})\end{array}$ & $\begin{array}{c}\text { Összesen } \\
(\mathrm{km})\end{array}$ \\
\hline $1959-1960$ & 87 & 14 & 101 \\
\hline $1961-1970$ & 66 & 354 & 420 \\
\hline $1971-1980$ & 559 & 808 & 1367 \\
\hline $1981-1982$ & 10 & 0 & 10 \\
\hline Összesen: & 722 & 1176 & 1898 \\
\hline
\end{tabular}

Ahogy az oly sokszor megtörtént a magyar történelemben, a reform nem váltotta be a hozzáfüzött reményeket. Ebben szerepe volt a hibás előfeltevéseknek,a közlekedésfejlesztési elképzeléseknek, valamint a pénzügyi fedezetlenségnek. Az előzetesen remélt önfenntartó folyamat hamar ráfizetésessé vált.

\section{KöZÚTHÁLÓZAT ALAKULÁSA}

1960-ban Magyarország állami közútjainak csak egyötödét tette ki a portalan utak aránya. A makadámutak 98\%-a 6 méternél keskenyebb volt, az úthálózat negyedén hiányzott a biztonságos előzéshez szükséges látótávolság. A közutak túlnyomó többségén lassan, alacsony sebességgel lehetett közlekedni, rossz müszaki állapotuk kedvezőtlenül hatott a gépjármüvek karbantartási költségeire. Mintegy 3000 helyen keresztezte egymást a vasút és közút, az egyszámjegyü főutakon átlag 3,6 km-enként, a kétszámjegyüeknél 5,8 km-enként, a sürü vasúti szintbeli keresztezés emelte a balesetek valószínüségét. ${ }^{31}$

A magyar gyorsforgalmi úthálózat első csírája 1960-ban jelent meg, amikor átadták a Törökbálint-Tatabánya kétszer egysávos országutat, mely az akkori korszerü elveknek megfelelően lett megépítve. 1965-re meghosszabbították Almásfüzitőig, amelyet 1961-től 1. sz. fóútnak,

\footnotetext{
28 A közlekedéspolitikai koncepcióról bővebben: Frisnyák 2013.

29 Unyi 1989. 22. és 29.

30 Mezei 2009. 267.

31 Autó-Motor. 1960. jan. 15. 3.
} 
1965-től M1 gyorsforgalmi útnak neveztek, és a fóváros határánál egy 8 km hosszú kétszer kétsávos közös bevezető szakaszt kapott az épülő balatoni (M7) gyorsforgalmi úttal. Ekkor vette át az M1 gyorsforgalmi út a Hegyeshalom-Győr-Komárom-Budapest útvonal Komárom-Dorog-Budapest szakaszának forgalmát, amelynek kapacitása már telítődött. ${ }^{32}$

A III. ötéves tervidőszakban évi átlag $500 \mathrm{~km}$ útépítést és útfelújítást terveztek a KPM-nél, ezt valamivel még túl is teljesítették. A korszerüsítések zöme a fóuthálózaton valósult meg, koncentrált korszerüsítési program készült az 1., 2., 3., 5., 6., 7., 71. és 84. számú főutak átépítésére. Összesen $2268 \mathrm{~km}$ út került korszerüsítésre, emellett $336 \mathrm{~km}$ bekötőút épült. 1967-ben a korszerüsítések 32\%-a, 1968-ban 43\%-a, 1969-ben 58\%-a zajlott az elsőrendű úthálózaton. ${ }^{33}$ Általánosságban elmondható, hogy a hatvanas évek az úthálózat kiépítésével, főutak rekonstrukciójával telt, míg a hetvenes évekre már a gyorsforgalmi úthálózat fejlesztése, a meglévő úthálózat biztonságosabbá tétele a jellemző.

A hetvenes években már a minőségi fejlesztésre tevődött át a hangsúly, az 1972-es útfejlesztési program keretében került sor a főközlekedési útvonalak kiszélesítésére, a legforgalmasabb szakaszokon vasúti kereszteződések alul- vagy felüljáróval való kiváltására, és egyes városok környékén elkerülő utak építésére. A IV. ötéves terv idején 1974-ig 1200 km közút bővítése és átépítése történt meg, $600 \mathrm{~km}$ új út építése mellett.

A fejlesztéseknek köszönhetően 1975-re a 29915 km állami úthálózat 97\%-át kiépítettnek lehetett minősíteni, 95\%-uk kapott pormentes burkolatot. A fóthálózat korszerüsítésekor az útburkolatot kiszélesítették legalább 7 méter szélességüre. ${ }^{34}$ Jelentősebb beruházásokat, mint például hosszabb fơútvonali szakaszok felújítását, átépítését, illetve új utak építését a KPM alá tartozó Betonútépítő Vállalat (BUV) és az Aszfaltútépítő Vállalat (AUV), valamint a Hídépítő Vállalat végezte az Út- és Vasúttervező Vállalat által készített tervek alapján.

Az első hazai, Budapestet a Balatonnal összekötő autópálya tervezése 1961-ben kezdődött nyugat-német minták alapján, a kivitelezés pedig 1962-ben indult. Az autópálya betonburkolattal épült meg, mivel nem állt rendelkezésre Magyarországon a feladatnak megfelelő teljesítményű aszfaltozó gép, illetve kellő mennyiségü aszfaltot sem tudott készíteni a magyar ipar. Az első 13 kilométer még kétszer kétsávos autópályaként épült meg 1966-ra, az 1. számú fơút közös budapesti bevezető szakaszaként. Innentől már csak a bal pályát építették tovább, ami 1971-re ért el Zamárdiig. A jobb oldali pályatest megépítése már gyorsabban zajlott, köszönhetően annak, hogy a földmunkák és alépítmények készítésekor már a teljes autópálya szélességét vették alapul, így 1975-re lett kész a teljes autópálya. ${ }^{35}$

1971-ben Minisztertanácsi határozat született az M1, M3, M5, M7 útdíjas autópályákból álló 450-500 km hosszú hálózat megépítésére 15 éven belül, amelynek megvalósítását nagyobb részben nyugati hitel segítségével tervezték! A Magyar Külkereskedelmi Bank valamint olasz, francia, német, brit és japán cégek közötti tárgyalások azonban elakadtak, a reformok 32 Magyar autópályák 1996. 5-9.

33 Ábrahám 1978. 39.

${ }^{34}$ MNL OL XIX-H-1-pp-5. 6. d. 608514/1961. sz. ügyirat

35 Ehhez az autópályához egy sajátos forgalmi megoldás kapcsolódik; 1964-től a nyári főszezonban, 1968-tól már májustól szeptemberig hétvégenként egyirányú közlekedést vezettek be a balatoni forgalomban. Vasárnap, illetve utolsó munkaszüneti nap délutánjától estéig a félpályás utat csak Pest irányában lehetett használni, Balaton felé csak a régi 7. számú fơuton illetve alsóbbrendủ utakon lehetett közlekedni. Szombat 14 órától vasárnap 22 óráig csak személyautók, szóló buszok és teherautók, valamint nemzetközi forgalomban résztvevő nyerges vontatók közlekedhettek. A második pályatest elkészültével, 1975-től megszünt a forgalmi szituáció. 
leállításával és az egyre romló gazdasági helyzet miatt 1976-ban törölték a programot. A fejlesztési tervet keretként megtartották sőt, kiegészítették azt egy a fővárost megkerülő körgyürüvel, de megvalósítására nem tüztek ki konkrét dátumot, a fejlesztésre pedig kizárólag állami forrást irányoztak elö.

A közlekedéspolitikai koncepció továbbfejlesztéséről tárgyaló országgyülés 1978-ban a következőképpen határozott: „Az országos közúthálózaton elsődlegesen a csomópontokat, hidakat, a városi átkelési és elkerülő szakaszokat kell fejleszteni, s új összekötö utakat kell épiteni. A szerkezet átalakitását, a sugaras-gyürüs föhálózati rendszer létrehozását a település- és közlekedésfejlesztés figyelembevételével fokozatosan kell megvalósitani. Az igények indokolják, hogy évente 35-45 kilométer gyorsforgalmú autóút, illetve autópálya épüljön...” A következő év tavaszán az MSZMP KB Gazdaságpolitikai Bizottsága ülésén is a közúthálózat gyürüs-sugaras rendszerü kialakítása mellett döntött, egyúttal kijelölve a gyorsforgalmi úthálózat legfontosabb irányait és megvalósításának ütemeit, kiemelve a nemzetközi és tranzitforgalom számára fontos irányokba való autópálya-építést. ${ }^{36}$

Időrendben a Győrnek tartó M1 gyorsforgalmi utat kezdték el építeni másodjára, jóllehet útvonalvezetése megelözte a balatoni útét. A már megépült Budapest-Tatabánya-Almásfüzitő közút Győrig tartó szakaszának korszerüsítése helyett végül „félautópálya” építését határozták el Tatabánya és Győr között, módosított nyomvonalon. 1966-ban indult meg a bal pálya elökészítési munkálatai, de a jobb pálya területeit is kisajátították. A generálkivitelező az Aszfaltútépítő Vállalat volt, míg a mütárgyakat és hidakat a Hídépítő Vállalat építette. Az aszfaltburkolattal épített gyorsforgalmi út lassan, 1977-re épült meg. Mivel a sok szintbeli kereszteződés és növekvő forgalom miatt rendszeressé váltak a dugók a főváros közeli részeken, ezért új nyomvonalon kétszer két sávos autópálya építéséről született döntés a Törökbálint-Bicske szakaszon, aminek megvalósítása 1978-ban kezdődött el. ${ }^{37}$

A félpályás építkezés az M3 autópálya kivételével mindegyik gyorsforgalmi út építésére jellemző volt a szocializmus alatt. A ,gyorsforgalmi út” és ,,autópálya” fogalmakat kissé kaotikusan használták, gyakran keverték a két fogalmat - ez is mutatja, hogy egy addig ismeretlen elem került a közúti közlekedésbe, aminek időbe került, hogy megtalálja helyét.

A 3. sz. főút már 1970-re telítődött, ezért 1973 őszén kezdték el építeni az M3 autópályát a BUV irányításával. Ezt már eleve kétszer két sávos aszfaltburkolatú autópályával tervezték, mivel az M7 építésének tapasztalatai rávilágítottak, hogy nem olcsóbb félpályánként megépíteni. A Gödöllőig tartó első szakaszt 1978-ban adták át, két év múlva ért el Hatvanig a gyorsforgalmi út. Budapesti bevezetése viszont csak 1982-re készült el, amikor is készen lettek a Kacsóh Pongrác úti felüljárók. ${ }^{38}$ Utolsóként a vizsgált kor autópályái közül meg kell említeni az M5 első szakaszát is, az Ócsáig tartó első szakasz építését 1978-ban kezdték el. ${ }^{39}$

Az említett főutak és gyorsforgalmi utak a fokozódó közúti közlekedés igényeit próbálták meg kielégíteni. A hatvanas évek közepén kötött nemzetközi egyezmények révén Magyarország úthálózatának egyes elemei bekerültek az európai közlekedési hálózatba, amikre külön elöírások vonatkoztak. A nyugati közlekedési rendszer „E” jelü útjai közül az E5 36 Magyar autópályák 1996. 14-18. Idézet: 17.

37 Magyar autópályák 1996. 44-45.

38 Magyar autópályák 1996. 47-48.; Autó-Motor. 1970 okt. 6. 6., 1975 júl. 21. 5., 1975 nov. 21. 3-5., 1977. 14. sz. 16-17., 1980. 9. sz. 4-5., 1980. 10. sz. 40-41.

39 Magyar autópályák 1996. 48-49. 
(London-Bécs-Budapest-Belgrád-Isztanbul), E15 (Hamburg-Berlin-Prága-Budapest-Bukarest-Constanza) és E96 (Rijeka-Nagykanizsa-Budapest-Miskolc-Kassa) útvonalak érintették a magyar közúthálózatot, míg a KGST „T” jelü útvonalai közül a T1 (Ungvár-Püspökladány) és T7 (Krakkó-Zólyom-Budapest) haladt át Magyarországon. ${ }^{40}$

\section{VASÚTHÁLÓZAT ALAKULÁSA}

A Magyar Államvasutak és általában a magyar vasúti közlekedés Rákosi-korszakban tapasztalt többszöri összeomlás közeli helyzete 1956 után kis mértékben javult, a csúcsra járatott rendszerbe több pénzt juttatott az állam. Nagyobb pályafelújítási program kezdődött még az ötvenes évek végén, a vasúti jármügyártás előbb a dízelesítés, majd a villamosítási program keretébe nagy lendületet vett a hatvanas években, de a személy- és teherkocsipark modernizációja is megkezdődött.

Néhány adat 1960-ból: a villamosított pályák hossza a teljes hálózat mindössze 3,4\%-át tették ki, a vágányok nagy részén alacsony tengelyterhelésű vonatok közlekedhettek, ami akadályozta a hatékony, gazdaságos teherszállítást. Sínek $60 \%$-a 30 évnél öregebb, a pályahálózat mindössze $12 \%$-a volt alkalmas 23 tonna tengelyterhelésre, és csak a vonalak 10\%-án lehetett legalább $100 \mathrm{~km} / \mathrm{h}$ sebességgel közlekedni. Hasonlóan kritikus helyzetet mutatott a jármüpark is, a teherkocsik és személykocsik több 60\%-ának kora meghaladta a 40 évet, ráadásul a személyvagonok 77\%-a még törékeny, fa szekrényvázas szerkezettel rendelkezett, illetve még 300 teherkocsiból átalakított úgynevezett szükség személykocsi (bocipullman) közlekedett. ${ }^{41}$

Az Országos Tervhivatal már hivatkozott 1960. júniusi összeállításában a következő 15 évben a vasút fejlődéséhez elkerülhetetlennek ítélte kistávolságú teherszállítás átterelését közútra a fokozódó távolsági és tranzit áruszállítások teljesítése érdekében. Ehhez elsődleges fontosságúnak ítélte a tengelyterhelés és sebesség emelését, fővonalon $125 \mathrm{~km} / \mathrm{h}$ sebesség és 23 tonna tengelynyomás, mellékvonalakon pedig $60 \mathrm{~km} / \mathrm{h}$ sebesség elérését tartották kívánatosnak. Ennek eléréséhez évente 300-320 km fövonali pálya átépítését, valamint 200-220 km mellékvonali pálya használt anyagból történő felújítását tartották elengedhetetlennek. Még ilyen forszírozott ütemben is csak 1980-ra fejeződött volna be a teljes hálózat rekonstrukciója. Új vasútvonal építésével nem számoltak, csupán távlati célként felmerült egy Székesfehérvár és Szolnok közötti Budapestet elkerülő vasúti gyürü megépítése, valamint Szeged Bajával és Pécscsel való közvetlen összekötése. A hangsúlyt a nemzetközi forgalmat bonyolító fővonalakon a II. vágányok (vissza)építésére, 1500-1600km vonal villamosítására és korszerü rendezőpályaudvarok építésére helyezték.

Vasúti vontatás terén a növekvő terhelés és sebesség miatt a dízelesítés és villamosítás volt az egyetlen megoldás. Még a szomszédos államokhoz viszonyítva is jelentősnek bizonyult mozdonyparkunk elmaradottsága. Teherkocsipark nagy része szintén elavult, kis raksúlyú típusból állt. 1975-ig 36000, utána további 11000 kocsi selejtezésével számolt, amelyek pótlására évente 3000-3500 teherkocsi beszerzésével kalkuláltak, így a korszerü kocsikkal a selejtezések mellett is $25 \%$-kal nőne a jármüállomány száma, $60 \%$-al a szállítási kapacitása. Személykocsik terén

\footnotetext{
40 Autó-Motor. 1974 febr. 21. 5.
}

41 Mezei 2009. 237. 
évente 200-250 db négytengelyes személykocsi beszerzését tartották kívánatosnak, hogy a régi, elavult kocsik selejtezése mellett is ki lehessen elégíteni a növekvő utasforgalmi igényeket. ${ }^{42}$

Tíz évvel későbbi, szintén 15 éves középtávú közlekedésfejlesztési programban is hasonló alapvetések szerepeltek. Elsődleges fontossággal az „A” kategóriába sorolt törzshálózat rekonstrukciója, és a vasútüzemi és irányítási folyamatok technológiájának fejlesztése, automatizálása jelent meg. A $3000 \mathrm{~km}$-es törzshálózatból $2000 \mathrm{~km}$ kerülne átépítésre a pálya 23 tonna tengelyterhelésre alkalmas hézag nélküli felépítménnyel, 120-140 km/h sebességet lehetővé tevő vonalvezetéssel, valamint önmüködő biztosító és forgalomirányító berendezésekkel. További 2000-2500 km „B” kategóriás vonal fejlesztését némileg alacsonyabb müszaki tartalommal, a forgalom igényeinek megfelelően $80-125 \mathrm{~km} / \mathrm{h}$ sebességre megfelelően ítélték meg. Mintegy 2200 km, a közlekedéspolitikai koncepció alapján „C” kategóriába sorolt kis forgalmú vasútvonal forgalmának közútra terelésével számoltak, további $1000 \mathrm{~km}$ vasútvonal sorsát pedig a gazdasági igényektől tették függővé.

Természetesen a vasúti jármüállománnyal kapcsolatos fejlesztési tervek is újra előkerültek a lényeg változatlanul hagyásával: az elavult vontató és vontatott jármüvek gyorsított ütemü selejtezésével és korszerü jármüvek egyidejü pótlásával úgy, hogy végeredményben a személy- és áruszállítási kapacitások bővüljenek. ${ }^{43}$

Mi valósult meg a fenti elképzelésekből? 1961-1975 között összesen 4803 km felépítményt cseréltek ki, a csúcsot 1962-ben érték el a pályamunkások, ekkor egyetlen év alatt 470 km-en cseréltek ki felépítményt. ${ }^{44}$ Igaz, az alépítményi hibák felszámolása ekkor még háttérbe szorult. Ezalatt a 15 év alatt a $100 \mathrm{~km} / \mathrm{h}$ vagy nagyobb sebességre alkalmas pályák hossza elérte a 3000 $\mathrm{km}-\mathrm{t} .{ }^{45} \mathrm{~A}$ legnagyobb átépítésekre a nagy forgalmú, nemzetközi személy- és teherszállításban használt vonalakon került sor. Természetesen egy vonal teljes átépítése korszerü felépítménynyel, biztosító berendezésekkel, állomásbővítésekkel és helyenként nyomvonal korrekciókkal több éven át tartott.

Mivel a pályaépítési és fenntartási munka nem csak nehéz és veszélyes, de a családtól való távollét is megnehezítette a pályamunkások életét, a hatvanas évektől felgyorsult a munkaerő-elvándorlás. Ezért és a pályaépítési munkák gyorsabb, gazdaságosabb elvégzése miatt a MÁV svájci Matisa, osztrák Plasser vasútépítő gépeket szerzett be, valamint a MÁV Központi Pályafenntartási Telepén gyártott hazai fejlesztésü ágyazatrostáló és aljköz-tömörítő gépeket. ${ }^{46}$ Ezeket gépláncba szervezve a korábbinál jóval rövidebb idő alatt végeztek pályaépítési és karbantartási munkákat. Teljes átépítés esetén a régi felépítmény elbontása után ha szükséges volt, az új vágány fektetése előtt az alépítmény megerősítésére is sor került különböző talajjavító rétegek terítésével, vagy rézsük, töltések megerősítésével. 1971-től 10 géplánc vett részt a pályaépítésben és fenntartásban. A fővonalak korszerüsítése során a pályát hézagnélküli felépítményüre

42 MNL OL XIX H-1-c. 26. d. 00239/1960. 8-22.

43 A közlekedés hosszútávú terve 1970. 67-72.

44 Felépítmény: vágány és zúzottkő ágyazat együttese. Ezalatt már az alépítmény található.

45 Horváth 2005. 47.

46 Ambrus 1985. 147. A MÁV építőipari szervezetének 35 éve, 1950-1985. Szerk.: Ambrus Zoltán. Budapest. 1985. (stencil) 147. 
építették át 48-as, majd 1969-től bevezetett 54-es sínrendszerrel, ${ }^{47}$ ami müszakilag és gazdaságilag kedvezőbb volt, valamint javult az utazási komfort is. ${ }^{48}$

A pályaépítési munkák tervezését és koordinálását a Közlekedés- és Postaügyi Minisztérium I. Vasúti Főosztálya Pályafenntartási és Építési valamint a Vasúti Hídépítési szakosztályok, 1969-es átszervezés után az Építési és Pályafenntartási szakosztály végezte. ${ }^{49}$ A kivitelezési munkákat a hat vasútigazgatóság pályafenntartási és építési ügyek osztályainak egy-egy építési főnöksége végezte, illetve egy-egy alkalommal kapacitáshiány miatt a Betonútépítő Vállalat is kapott vasútépítő megbízásokat. ${ }^{50}$

A Rákosi-korszak után már nem épült új vasútvonal egyetlen kivétellel, 1969. június 30án adták át a 8 km hosszú Villány-Nagyharsány vonalat, hogy a nagyharsányi mészkő, illetve a tervezés alatt álló Beremendi Cementmü termékei gyorsabban tudjanak eljutni fỏvonali hálózatra. ${ }^{51} \mathrm{~A}$ II. hároméves tervidőszak alatt $715 \mathrm{~km}$ felépítmény került felújításra, $750 \mathrm{~km}$ pálya lett hézagnélkülire átépítve és mintegy 4000 csoport kitérőt cseréltek ki, vagy újítottak fel. ${ }^{52}$

A hatvanas években sorra indultak a nagyobb pályakorszerüsítések. Az egyik legfontosabb beruházás a Budapest-Miskolc fővonal villamosításának befejezése 1962. november 17-én, illetve annak meghosszabbítása a nyíregyházi deltán át Záhonyig (1967. december 29), valamint a Budapest-Szolnok-Debrecen-Nyíregyháza vonal villamosítása és Debrecen-Záhony szakaszon második vágány megépítése volt. ${ }^{53}$ A debreceni fővonalon 1964-ben készült el a II. világháború után anyaghiány miatt kényszerből felbontott második vágány visszaépítése Kisújszállás és Debrecen között. Szintén ebben az évtizedben újult meg az észak-balatoni vasútvonal, bár a balatonfüredi állomásépület csak 1973-ra készült el.

1962. december 11-én helyezték üzembe az első korszerü, jelfogós Integra Dominó 55 típusú állomási biztosító berendezést Vámosgyörkön. Az állomási és vonali biztosítóberendezések túlnyomó többsége elavult volt, ennek ellenére a biztonságos és gyors közlekedést elősegítő automata rendszerek csak lassan terjedtek el az országban, 1971-ben adták át a 100. állomási

47 48-as és 54-es sínrendszer: egy folyóméter sín tömege 48,3 vagy 48,5, illetve 54,4 kg volt. A sínek profilja némiképp eltérő volt, ezért különböző méretű rögzítőszereket alkalmaztak fektetésükkor. Fővonali átépítésekkor vasbeton keresztaljakat használtak, melyeket a lábatlani cementgyár állított elő.

48 A közelben felállított kötőtelepeken szereltek össze keresztaljakat és sínszálakat a szükséges kapcsolószerek segítségével 24 méteres hosszban, ezeket nevezik sínmezőknek. Miután elkészült az alépítmény és a zúzottkő ágyazat terítése, portáldaruk segítségével sínmezőket fektettek le, a sínszálakat hevederekkel rögzítették egymáshoz. Ezután gépláncokkal elvégezték a felépítmény vertikális és horizontális irányú beszabályozását. Miután kellően beágyazódott a pálya, a sínszálakat vagy egyenként összehegesztették, vagy kicserélték azokat 120-126 méteres sínszálakra, amelyeket a kötőtelepen hegesztettek össze öt darab 24 vagy hat darab 21 méteres szálból és speciális hosszúsínes szállítókocsikkal juttattak el rendeltetési helyükre, majd a már lekötött sínszálakat is összehegesztették. Így az új pálya felépítménye hézagnélküli lett, ezáltal megszűnt az illesztéseken átgördülő kerekek kattogása. A kibontott anyagok felhasználható részeit mellékvonalak korszerüsítésekor használták fel újból.

49 Horváth 2005. 76.

50 Horváth 2005. 155., 163., 165. és 169. MÁV Vasútigazgatóságok Építési Főnökségeinek székhelyei: Budapesti igazgatóság - Budapest, Miskolci igazgatóság - Miskolc, Debreceni igazgatóság - Debrecen, Szegedi igazgatóság - Szentes, Pécsi igazgatóság - Dombóvár, Szombathelyi igazgatóság - Celldömölk (ide tartozott a GySEV magyarországi hálózatának karbantartása is). Ezenkívül Budapesten müködött még a MÁV Hídépítő Főnökség, MÁV Villamos Felsővezeték Építési Főnökség és a MÁV Budapesti Magasépítő Főnökség. Horváth 2005. 251-253.

51 Vasút. 1971/2. 13-14.

52 Vasút. 1961/1. 1-2.

53 Mezei 2009. 262.; Vasút. 1962/2. 7., 1967/9. 24. és 1967/12. 1. 
Dominó berendezést Göd állomáson. ${ }^{54} \mathrm{Az}$ elektronikus biztosító berendezések elterjedése további lehetőségeket rejtett magában, mint a mozdonyokra szerelt biztonsági rendszerek, illetve egy vonalszakasz vagy akár egy egész vonal egyetlen központból történő irányítása. Utóbbira példa az 1971 júliusában üzembe helyezett Nyíregyháza-Mezőzombor vonal központi forgalomirányító berendezését Debrecenben, amit később kiegészítettek a Nyíregyháza-Záhony vonallal is. ${ }^{55}$

A III. ötéves terv alatt folytatódott a Rákos-Újszász-Szolnok, ${ }^{56}$ Hatvan-Újszász, Nagykanizsa-Szombathely, Győr-Sopron, Porpác-Hegyeshalom, Ukk-Zalaegerszeg, Cegléd-Szeged, ${ }^{57}$ Kiskunhalas-Baja-Dombóvár és Komárom-Székesfehérvár ${ }^{58}$ vonalak átépítése, valamint elkezdődött a Budapest-Vác-Szob vonal korszerüsítése is. 1971-ben csehszlovák szakemberek segítségével villamosításra került az egész vonal. Nem ez volt az Elektrizace Železničny Praha és az Automatizace Železničny Dopravy vállalatok első munkája Magyarországon, kapacitáshiány miatt már részt vettek a fővárost Szolnokon át Nyíregyházával összekötő vasútvonal 1968-1970 közötti villamosításában. Amíg az EZP a munkavezeték kiépítését végezte, az AZD hírközlési vonalkábelt fektetett.

A metróépítkezés miatt 1967 és 1970 között átépítették a Baross teret és a Keleti pályaudvart, csarnoki vágányok hosszából elvéve alakították ki a lépcsősort az aluljáróhoz. ${ }^{59} 1966-1970$ között a tervezett 1650 km nyílt vonali és $450 \mathrm{~km}$ mellékvonali és iparvágány korszerüsítése helyett $1100 \mathrm{~km}$ nyílt vonali és 380 km mellékvágány, iparvágány rekonstrukciója készült el. A 23 tonna tengelynyomású pályák hossza $4300 \mathrm{~km}$-re nőtt, $100 \mathrm{~km} / \mathrm{h}$ és annál nagyobb sebességre alkalmas pályák hossza 800 km-rel, míg a hézagnélküli felépítménnyel rendelkező pályák hossza 1100 km-rel, a villamosított pályák hossza $391 \mathrm{~km}$-rel gyarapodott. ${ }^{60}$

A hetvenes években folytatódott a vasútvonalak rekonstrukciója, de szervezési és munkaerő problémák miatt a IV. ötéves terv alatt majdnem a felére esett vissza a felépítménycserék üteme. Erre a periódusra $2000 \mathrm{~km}$ felépítménycserét és $280 \mathrm{~km}$ hosszon villamosítást terveztek. A pályaépítési és karbantartási munkák gyorsabbá tételéért a MÁV nagyteljesítményű pályaépítő gépeket gyártott, illetve vásárolt Svájcból és Ausztriából. ${ }^{61}$ 1971-ben tíz gépláncot állítottak fel, hogy biztosítsák a fővonalak karbantartását. ${ }^{62}$ 1971-1972-ben megépült a Debrecen-Nyíregyháza szakasz második vágánya, ami jelentősen növelte a szovjet-magyar forgalom szempontjából

\footnotetext{
54 Mezei 2009. 245; Vasút. 1971/12. 3.

55 Mezei 2009. 281.; Vasút. 1971/6. 8.

56 Talán ezt a vonalat építették át a leglassabb ütemben, holott jelentős nemzetközi teher- és személyforgalmat bonyolított le a szintén jelentős belföldi forgalom mellett. 1963-ban kezdődött meg a második vágány építése és csak 1973-ra fejezték be a munkálatokat. Mezei 2009. 286.

57 Cegléd-Szeged vonal átépítési munkálatai 1963-1967 között folytak, de az utómunkálatokat 1968-ben is végeztek, míg Kiskunfélegyháza állomás átépítése és kibővítése még a hetvenes évek elején is tartott. Vasút. 1966/9. 19-20. és 1971/9. 6 .

58 Nemzetközi vonatok miatt fővonali rangúvá átépített vonalat a régi pályától pár méterre építették meg, így az építkezés közben zavartalanul zajlott a forgalom.

59 Vasút. 1967/4. 30-31. A metró első szakaszának átadásával megszüntették a gödöllői HÉV Kerepesi úti végállomást és az Örs vezér terére helyezték át. A feleslegessé vált sínpár egy részét felbontották, így kibővíthették a közúti pályát.

60 Vasút. 1971/3. 1-6.

61 Mezei 2009. 277., 281., 286. és 307.; Vasút. 1971/8. 11.; Horváth 2005. 271.

62 Vasút. 1972/4. 21-22.
} 
kulcsfontosságú vonal átbocsátó képességét. Az évtized legnagyobb beruházását a hegyeshalmi vonal Kelenföld-Tatabánya szakaszának átépítése jelentette. Egyes szakaszokon új nyomvonalon épült meg a pálya - így szünt meg a forgalom a híres-hírhedt biatorbágyi viadukton - emiatt az építkezés még a nyolcvanas években is zajlott. A hetvenes években több szakaszban korszerüsítették a miskolci fövonalat, valamint a Miskolc-Szerencs-Záhony vonalat, mivel a hatalmas forgalom miatt idő előtt elhasználódott a felépítmény.

Az olajárrobbanás miatt megemelkedett a gázolaj ára, így újra kellett gondolni a dízelesítési és villamosítási programot. A villamosítás és a villamos mozdonyok beszerzése ugyan jóval költségesebb a dízelmozdonyoknál, hatásfokuk és teljesítményük viszont jóval nagyobb a belsőégésű motorral üzemelő vontatójármüvekénél, így már középtávon is gazdaságosabb megoldást nyújtva. Arról nem is beszélve, hogy a gyenge minőségü hazai szénből előállított áram jóval kevesebbe került, mint az olajimport. Mindezek miatt nagy lendületet vett a hetvenes években a fővonalak villamosítása.

A hetvenes években elkészült néhány fontosabb vasútállomás rekonstrukciója is; Budapest Déli pályaudvar 1976-ban nyerte el mai formáját, Budapest Nyugati pályaudvar rekonstrukciója és bővítése 1977-1979 között történt, Szolnok vasúti csomópont rekonstrukciója 1975-ben fejeződött be, de a Debreceni állomás átépítése, illetve a GySEV soproni új állomásépülete is ebben az évtizedben készült el.

A mellékvonalak korszerüsítése, egyszerüsített átépítése a fővonalakról kibontott sínekkel és általában vasbetonaljjal történt, mint például Hódmezővásárhely-Makó, Orosháza-Mezőhegyes vagy Kál-Kápolna-Kisújszállás mellékvonalakon. Ezzel a megoldással sikerült a korábbi 20-30 km/h sebességet $60 \mathrm{~km} / \mathrm{h}$-ra, a 12 tonna körüli tengelyterhelést $18-20$ tonnára emelni. ${ }^{63}$

2. táblázat: Vasúthálózat hossza 1960-1980

\begin{tabular}{|l|c|c|c|c|}
\hline \multirow{2}{*}{ Év } & $\begin{array}{c}\text { Vasútvonalak } \\
\text { építési hossza } \\
\text { összesen }\end{array}$ & $\begin{array}{c}\text { Ebből kétvágányú pá- } \\
\text { lyák építési hossza }\end{array}$ & $\begin{array}{c}\text { Az összes építési } \\
\text { hosszból villamosított }\end{array}$ & $\begin{array}{c}\text { Vasútvonalak } \\
\text { vágányhossza }\end{array}$ \\
\cline { 2 - 5 } & \multicolumn{4}{|c|}{ Kilométer } \\
\hline 1960 & 10307 & 958 & 469 & 14963 \\
\hline 1965 & 10069 & 1020 & 557 & 15124 \\
\hline 1970 & 9514 & 1108 & 935 & 14780 \\
\hline 1975 & 8740 & 1159 & 1303 & 13513 \\
\hline 1980 & 8142 & 1179 & 1613 & \\
\hline
\end{tabular}

3. táblázat: Vasúti felépítménycserék 1960-1980

\begin{tabular}{|l|c|c|c|c|}
\hline Évek & Kicserélt hossz $(\mathrm{km})$ & Éves átlag $(\mathrm{km})$ & Éves maximum & Éves minimum \\
\hline $1961-1965$ & 2065 & 413 & 470 & 377 \\
\hline $1966-1970$ & 1566 & 313 & 375 & 257 \\
\hline $1971-1975$ & 1172 & 234 & 318 & 155 \\
\hline $1976-1980$ & 1721 & 344 & 355 & 332 \\
\hline
\end{tabular}

\footnotetext{
63 Vasút. 1971/8. 8-9. és 1972/12. 32.

64 Horváth 2005. 45.

65 Uo.
} 
Az adatok rámutatnak a pályavasút sajátságos fejlődésére. Az 1980-as évek legelejéig emelkedő vasúti teherszállítások olcsó és gyors közlekedést igényeltek. Míg a kétvágányú pályák hossza alig 200 km-rel nőtt a vizsgált 20 év alatt (1945 és 1990 között összességében nem bővült 500 km-nél többel a kétvágányú pályák hossza), a villamosított pályák hossza majdnem megnégyszereződött, a nyolcvanas években pedig újabb lendületet vett a vasúti villamosítás.

A jármüparkban is jelentős változások zajlottak le, a vizsgált korszak végére töredékére csökkent a gőzvontatás aránya. A vontató jármüpark cseréjét részben importtal, részben licencejog vásárlásával, részben a Ganz-MÁVAG önálló fejlesztéseivel sikerült véghezvinni. Személykocsik terén elsősorban a hazai ipartól szerzett be jármüveket a MÁV, kisebb részben csehszlovák és kelet-német kocsikat is vásárolva, teherkocsik terén - a hazai gyártás megszünésével - szinte kizárólag a KGST országaiból vásárolt a MÁV.

\section{ÚJ KIKÉPZÉSI RENDSZERŰ ALAKULATOK LÉTREHOZÁSA}

1964 április 25-én adta ki a honvédelmi miniszter 0012/1964 számú parancsát, melyben elrendelte a népgazdaság katonai munkaerővel történő megsegítésére új kiképzési rendszerü alakulatok felállítását. ${ }^{66}$ A parancs szerint ,„1964 június 29-ig fel kell állítani egy közlekedési dandárt és egy általános müszaki dandárt. A közlekedési dandárt a Magyar Néphadsereg müszaki fönökének, az általános müszaki dandárt pedig a Polgári Védelem Országos Parancsnokság törzsfönökének rendelem alá. "67

Magyarországon nem volt szokatlan a 20. században katonákat különböző gazdasági munkák elvégzésére vezényelni, elég a visszacsatolt Észak-Erdélyben 1941-1942-ben épített 48 km hosszú stratégiai fontosságú Szeretfalva-Déda vasútvonal építésére gondolni. A II. világháború magyarországi harcainak befejeződésével azonnal megkezdődött a honvédség szervezése, hogy a szövetséges hatalmak oldalán fejezhesse be Magyarország a háborút. Erre végül nem került sor, a szervezni kezdett alakulatokat viszont müszaki alakulatokként állították fel, hogy részt vegyenek az ország közlekedési és hírközlési rendszerének helyreállításában. A honvédség valamennyi alakulata és intézete meghatározott idejü közmunkavégzésre volt köteles 1945 és 1947 között. A többször átszervezett hídépítő és vasútépítő egységek utolsó nagyobb munkája az 1946-1947ben újjáépített tiszaugi közúti Tisza-híd volt. ${ }^{68} 1949-1952$ között erőltetett hadseregfejlesztés zajlott a harmadik világháborúra való készülés jegyében. A politikailag megbízhatatlannak tartott fiatalokat az MN Hadtápfönökség alá tartozó építő zászlóaljakba sorozták, amik honvédségi objektumok építésében vettek részt. A minisztertanács 1953. augusztus 14-i ülésen 504/8/1953 számon hozott határozatot a hadseregből leszerelő sorállomány bányászatba tereléséről. Elsősorban ide is politikailag megbízhatatlannak tartott sorkatonákat küldtek, rendkívül rossz körülmények közé. 1954 augusztusától emberibb körülmények közé kerültek a katonák, ellátásukat és alkalmazásukat a Honvédelmi Minisztérium és a Szénbányászati Minisztérium közötti megállapodás

66 Fodor 2008. 302.

${ }^{67}$ Hadtörténeti Levéltár (HL) MN Különgyüjtemény. Hargittai Emil: Rendeltetésük szerint építő munkát végző MN csapatok tevékenysége. 1986. Kézirat. 182. Továbbiakban: Hargittai.

68 HL. MN Különgyüjtemény. Halassy Géza-Kürtös Lajos: Az alaprendeltetéstől eltérő tevékenységek története. In.: A Magyar Néphadsereg története 1945-1980. Tanulmánygyűjtemény. Kézirat. 2. kötet. 377-380. Halassy Géza a 150. közlekedési dandár törzsfőnöke volt 1969-1971 között. Továbbiakban: Halassy-Kürtös. 
szabályozta. 1956 októberéig müködtek ezek az alakulatok ekkorra 8502 fö alkotta a csapatok összlétszámát a kezdeti 2110 fös létszámmal szemben. 1956 április 1-én a mezőgazdaság és építőipar kisegítésére állítottak fel csapatokat. 6000 fő az Építésügyi Minisztérium, 1050 fő a Közlekedés- és Postaügyi Minisztérium, 9252 fő a Szénbányászati Minisztérium és 200 fő az Épületkivitelező Vállalat munkaterületére szerveződött. Kisegítő müszaki katonai alakulatok társadalmi megítélése kedvezőtlen volt, munkaszolgálatnak tekintették, ezért már szeptember 28-án javaslatot tettek felszámolásukra. A forradalom alatt egyszerűen feloszlottak ezek az egységek, hivatalosan december 31-én intézkedett a minisztertanács feloszlatásukról. ${ }^{69}$

1956 után sem szakadt meg a népgazdaság és a hadsereg közvetlen kapcsolata. A konszolidációs korszak során 787 millió forint értékben adott át anyagokat, ruhákat, gépeket, építési anyagokat, technikai eszközöket, épületeket a néphadsereg vállalatoknak és termelő szövetkezeteknek feleslegeiből. Mind a mezőgazdaság, mind az ipar folyamatosan igényelt katonai segítséget termés betakarításhoz, szállításhoz és építkezéshez. Az egy időben jelentkező igények sok erőt kötöttek le, így több egység és alegység ${ }^{70}$ elmaradt éves kiképzési programjától. Korszerübb fegyverzet kevesebb katonát igényelt, ugyanakkor a tömeghadsereg koncepció miatt mindenkit bevonultattak. Hogy ne tünjön munkaszolgálatnak és a hadseregnek is haszna legyen (kiképzés révén és anyagi téren), ezért új kiképzési rendszerü müszaki csapatokat hoztak létre. MSZMP PB 1963 febr. 18-i határozata adott kezdölökést, mely új kiképzési rendszerü müszaki csapatok felállítását tüzte ki célul. A Magyar Néphadsereg vezérkari fönökének 1963 február 27-i tájékoztatója szerint „,... ugyanolyan katonák lesznek, mint a többi fegyvernemhez behívottak; a behívás, bevonulás azonos a többi fegyvernemmel. Kéthavi kiképzést kapnak az itt szolgálók, s ugyanolyan fegyveres alakulatnak számítanak mint a többi fegyveresek; a hídépitésben, útépitésben, vasútépitésben, vezetékes híradás létesitésében és más tömegmunkában vesznek részt; a hadsereg részt vesz a népgazdaság legfontosabb munkáiban; a kiképzésen belül a csapatok egyben „M” müszaki tartalékot képeznek; a HM katonai irányitása alá tartoznak, a munka gyakorlati irányitását az illetékes foglalkoztató minisztériumok végzik; a katonák a megdolgozott bér legalább egyharmadát megkapják. "71 1963-as év az új kiképzési rendszerü csapatok alkalmazásának elvi feltételrendszereinek kidolgozásával telt el, majd a 3144/1964 számú minisztertanácsi határozat alapján került sor a már idézett 0012/1964 számú honvédelmi miniszteri parancsra.

A nehéz fizikai munka miatt a katonák katonai norma szerinti élelmezését pótlékkal javították fel. Az állomány elhelyezéséről, ebédről, védőöltözetről és tisztálkodási lehetőségekről a foglalkoztatónak kellett gondoskodnia, míg katonaruhát és munkaruhát a néphadsereg biztosított. Munkáltató vállalatok kötelesek voltak biztosítani az alegységek elhelyezési körülményeit. ${ }^{72} \mathrm{~A}$

69 Halassy-Kürtös. 382-384.

70 Egység: önálló zászlóalj és annál magasabb egység, például ezred, dandár, stb. Alegység: ezred vagy dandár alárendeltségébe szervezett nem önálló zászlóalj, század.

71 Fodor Kálmán. 302.; Halassy-Kürtös. 388-389. „M” tartalék: mozgósítási tartalékot jelent, vagyis szükség esetén a hadköteles korúak behívását a hadseregbe.

72 MÁV Szolgáltató Központ, Archívum (továbbiakban MÁV Arch.). LV 11148. d. 110426/1972. MÁV Végrehajtási utasítás sorállományú honvéd személyek gyakorlati szakkiképzéséröl. Az utasítás részletesen szabályozta a munkatervek készítését, a katonák foglalkoztatási és elhelyezési körülményeit, élelmezési és egészségügyi ellátásukat. Kitért a különböző előmunkás és gépkezelői tanfolyamok szervezésére is, illetve részletesen szabályozta a katonai munkaerőért fizetendő bérek és jutalmak elszámolását (a honvédek által végzett munkáért a civil alkalmazottakkal megegyező bérezést kellett fizetnie a MÁV-nak a HM-nek). 
katonai alapkiképzés ideje alatt a HM térítette meg a foglalkoztatók költségeit az illetékes tárcáknak. Gyakorlati szakkiképzés ideje alatt önállóan gazdálkodtak az alakulatok, a hiányt állami támogatásból a HM térítette meg. Honvédelmi érdekből a gyakorlati szakkiképzést bármikor fel lehetett függeszteni, a megállapodásokat minden évben meg kellett újítani. ${ }^{73}$

Két hónap alapkiképzés és 22 hónap gyakorlati szakkiképzésre lett felosztva a sorkatonai idő, ez a gyakorlatban úgy módosult, hogy december közepétől február végéig katonai kiképzés zajlott és márciustól december közepéig a gyakorlati szakkiképzésnek hívott munkavégzés, ezért december végén, január elején történtek az újoncok bevonultatása és december végén a leszerelés. ${ }^{74}$ Idővel a szakképzettséggel nem, de 8 általánossal rendelkező katonák számára szakmunkásképzések indultak a foglalkoztató vállalatok segítségével, ezek rendes, államilag elismert szakmunkás bizonyítványt adtak a tanfolyamot eredményes vizsgával abszolváló katonáknak, általában hegesztő, vasbetonszerelő, kőmüves, ács-állványozó, és más hasonló szakmában. Ennek két előnye is volt, egyrészt a katonák szakmát szereztek sorkatonai idejük alatt, másrészt enyhítették a képzettebb munkaerőhiányt és a vállalatok így próbáltak munkavállalókat szerezni a leszerelő katonák közül. Akik nem rendelkeztek általános iskolai végzettséggel, azok számára a közeli iskolák tanáraival kötöttek szerződést a zászlóaljak, hogy gyakorlati szakkiképzés utáni heti 2-3 alkalommal történő foglalkozásokat tartsanak. ${ }^{75}$ Általában felső tagozatos általános osztályokat indítottak, de előfordultak olyan esetek is, amikor funkcionálisan analfabéta sorkatonákat alsó tagozatos osztályba kellett íratni. Ezek az esti iskolák a szegényebb, nehezebb sorsú fiataloknak próbált mentőövet adni, év végén tett eredményes vizsga esetén bizonyítványt kaptak. A Honvédelmi Minisztérium és a Müvelődésügyi Minisztérium 126/74 számú együttes utasítása szerint sorkatonák az Országos Szakmunkásképzési Jegyzékben szereplö szakmákból képesítést szerezhettek, ha megfelelnek a követelményeknek és eredményes vizsgát tesznek szolgálati idejük alatt. ${ }^{76}$ Sajnos a dandár iratai között nem maradt fenn összesített statisztika a beiskolázott honvédekről, így csak becsülni lehet létszámukat, nagyságrendileg meghaladhatta az ezret. Napi munkaidőt ebéddel, ki- és bevonulással együtt 10 órában határozták meg, indokolt esetben 12 órára lehetett kibővíteni egy müszakot. Két dandár került

73 Hargittai. 181.; MÁV Arch. AE 15107. d. 2400/1977. Honvédségi létszám 1977. évi foglalkoztatási tervének jóváhagyása. 1977 márc. 12.

74 A sorkatonai szolgálat időtartamát legfeljebb három évben szabta meg az 1960:IV törvény 24§-a, azzal a kitétellel, hogy az egyes fegyvernemeknél és szolgálati ágaknál, illetve évfolyamoknál a honvédelmi miniszter állapítja meg a tényleges sorkatonai időt. A sorkatonai idő valójában - leszámítva néhány különleges feladatú alakulatot - két év volt.

75 HL MN f. 4058-4063/84 mikrofilm. 150. ddr. parancsnokának 67/1973 intézkedése. MSZMP KB 1972 június 14 15-i határozata rendelkezett az állami oktatás fejlesztéséről. Az iskolázottsági szint javult, de még mindig sok fiatal nem rendelkezett 8 általános végzettséggel sem. A dandárnál sorkatonai szolgálatot teljesítő 1949-54-es évfolyamú legénység 23\%-a szintén nem fejezte be általános iskolai tanulmányait. Közülük 53 fö (föleg cigány) még az alsó 4 osztályt sem végezte el, gyakorlatilag analfabétáknak számítottak. MN 4518 sorállományának 32,9\%-a, MN 1737 29,5\%-a, MN 5320 27\%-a nem fejezte be a 8 általánost. Kezdeti próbálkozások az MN 1333-nál, MN 6050-nél és MN 1205-nél történtek. MN 5320-nál a 109 főből 80 iratkozott be, akik nem végezték el a 8 általánost. Alakulatok széttagoltsága nehezítette a probléma megoldását. Dandárparancsnok utasította az alegységeket, hogy vegyék fel a kapcsolatot a helyi tanácsokkal és helyi iskolák vezetésével. Pedagógusokkal közösen mérjék fel a tennivalókat. Költségeket végső esetben a dandár állja, valamint irodai, étkezdei vagy klubhelyiségeket biztosítottak a tanuláshoz. Felhívta a zászlóaljparancsnokok figyelmét, hogy a középiskolai és főiskolai végzettségű sorkatonákat is vonják be társaik oktatásába. Mivel az iratokat elsősorban mikrofilmen kutattam, ezért hivatkozásoknál is a mikrofilmek számát fogom megadni.. Lábjegyzeti hivatkozásnál a dandárt ddr-nek, a zászlóaljat zlj-nek rövidítem.

76 HL MN f. 4170-4177/84. 153. zlj 53/1974 számú parancs. 
felállításra, a 150. közlekedési müszaki dandár (fedőszáma MN 3705) amely a közlekedési és hírközlési infrastruktúra építésében vett részt, és a 160. általános müszaki dandár (MN 7560), amely nehézipari beruházásokon és lakótelepi építkezéseken vett részt.

Miért kerültek felállításra ezek az alakulatok? A hidegháború totális pusztításával fenyegetett Európában hatalmas tömeghadseregek jöttek létre. Magyarország sem lehetett kivétel ez alól, ugyanakkor az ötvenes évek eleji őrült tempójú és átgondolatlan hadseregfejlesztését nem lehetett újrakezdeni. Szolidabb keretek között, de a Kádár-korban is tartó nehézipari beruházások rengeteg munkaerőt szívtak el más területekről, így a hadsereg maradt több vállalat utolsó lehetősége munkaerő ideiglenes pótlásában. A hadsereg normális müködését viszont zavarták a népgazdasági segítségkérések, ezért került megszervezésre a fent említett két dandár, illetve rajtuk kívül még egy építőezred, amely elsősorban honvédségi építkezéseken dolgozott - így a kecske is jól lakott és a káposzta is megmaradt. Ráadásul pénzt is hoztak a Honvédelmi Minisztériumnak, miután kellően bejáratódott a rendszer. 1970-től mindkét dandár önfenntartóvá vált, bevételeikből fedezni tudták működési költségüket, így nem igényeltek állami támogatást. ${ }^{77}$ 1976. évi I. törvény a honvédelemről $16 \S$-a a fegyveres erők feladatai között új feladatként jelent meg a közremüködés népgazdasági feladatok végrehajtásában, valamint részvétel az ifjúság nevelésében. Az alakulatok lényegét a dandárparancsnok 1978. évi feladatokat kijelölő szolgálati használatú parancsában világította meg a legélesebben. „, A gyakorlati szakkiképzés népgazdasági jelentőségének egyik jellemző tényezője, hogy stabil, nem fluktuáló, fegyelmezett munkaeröt biztositunk a népgazdaságnak, amely lehetövé teszi a szükséges mérvü átcsoportositásokat, illetve a munkaerő regionális elosztását. Ezen túlmenöen jelentősen hozzájárulnak a KPM tárca építőipari tevékenységet folytató vállalatnál fennálló munkaerö-hiány csökkentéséhez. " 78

Gyakorlati szakkiképzésnek hívott munka alatt rombolási és építési, helyreállítási ismereteket szereztek egy-egy munkaterületen. Ezekre az ismeretekre és képességekre egy esetleges atomháború során számított a katonai vezetés. A kétéves sorkatonai idő alatt fokozatos gyakorlással, szoktatással el kellett érni, hogy a sorállomány három órán át képes legyen gázálarcban tevékenykedni. ${ }^{79}$ Háború esetén ezen alakulatok elsődleges feladata a közlekedési és hírközlési infrastruktúrában keletkezett károk helyreállítása, valamint újak építése lett volna. Emellett még szerepelt a kiképzési tervben az ellenség ejtőernyős csoportjainak bekerítése és felszámolása - a kiképzésből és a fegyverzetből ítélve erre elég kevés esélye lett volna bármelyik útépítő vagy vasútépítő alegységnek.

Az egyes zászlóaljaknak meg volt határozva háború esetén elsődleges müködési területük, ezt jól mutatja az ERŐD '77 törzsvezetési gyakorlat, amelyet a 156. vasúti műszaki zászlóalj állománya hajtott végre. ${ }^{80} \mathrm{~A}$ gyakorlat célja a zászlóalj feladatainak megtervezése és szervezése háborús körülmények között. Szakmai vonatkozása a vasúti közlekedés biztosítása, rombolt vasúti hidak helyreállítása, illetve pótlásához 1600 tonnás TS-uszályhíd bejárati részeinek építése, valamint az ezekkel kapcsolatos feladatok megtervezése, megszervezése és végrehajtásuk

\footnotetext{
77 Hargittai. 182. Ehhez szükség volt az 1968-as gazdasági reformra is, a vállalatok nagyobb önállóságot kaptak, így jobban tudtak élni az új kiképzési rendszerü alakulatok által nyújtott lehetőségekkel.

78 HL MN f. 4373-4382/87. 150. ddr. 150/1977 szolgálati használatú parancs. 21.

79 HL 5265-5266/82. 152. zlj. 13/1965 szolgálati használatú parancs.

80 HL. 4423-4426/87. 156. zlj 22/1977 szolgálati használatú parancs.
} 
irányítása volt. ${ }^{81}$ Vasúti hídépítő erők egy része Dunaújváros térségében a megkezdett 1600 tonnás TS vasúti híd be- és kivezető pályaszakaszának építésére, más részei pedig a szolnoki vasúti híd helyreállítására készült fel. Közúti hídépítő erők feladata a Sió-Sárvíz csatorna Szabadbattyán-Szekszárd szakaszán lévő közúti hidak rombolás esetén történő helyreállítására, illetve a szolnoki tiszai közúti híd helyreállítása volt. A dandár többi alegysége „A” változatban a Záhony-Debrecen-Hajdúszoboszló és Hajdúszoboszló-Szolnok, „B” változatban a Nyékládháza-Vámosgyörk-Szolnok és Szolnok-Cegléd-Kecskemét-Szalkszentmárton vonalszakaszon lévő vasúti felépítmény rombolás esetén történő helyreállításra készült fel.

Amint az a fentebbiekből is jól látszik, a közlekedési müszaki katonák alapvető feladata a kelet-nyugat közlekedési irány biztosítása lett volna egy háború esetén, hogy a két országrész között fennmaradjon a közlekedési kapcsolat, valamint a Szovjetunió felől érkező utánpótlás minél gyorsabban jusson el a frontra. Másodlagos feladata a hátország rendjének fenntartása, vezetési pontok biztosítása és a polgári védelem segítése lett volna. Ezt a cseppet sem egyszerü háborús feladatot kellett volna ellátnia szükség esetén a 150. dandárnak, a továbbiakban ennek az egységnek 1964-1977 közötti történetét próbálom rekonstruálni, a fennmaradt levéltári források alapján.

\section{A KÖZLEKEDÉSI DANDÁR TEVÉKENYSÉGE}

1964 október 2-i keltezéssel az MN Müszaki Főnöke, Hersiczky Lajos vezérőrnagy készített jelentést az MSZMP Magyar Néphadsereg Pártbizottság Végrehajtó Bizottságának a 150. közlekedési müszaki dandár helyzetéről és erkölcsi-politikai állapotáról. ${ }^{82} \mathrm{~A}$ jelentésből kiderül, hogy a dandár felállításába csak 1964 márciusában kapcsolódott be a Müszaki Főnökség, addigra már elkészült az állománytábla tervezete és meg volt határozva az április 28 -i felállítási dátum is. A dandár törzsének személyi állományával sikerült megértetni, hogy fontos honvédelmi érdek miatt került megszervezésre az egység. A hivatásos tiszti és tiszthelyettesi állomány feltöltése nehezen ment szakképzettségi, egészségügyi és/vagy családi problémák miatt, a dandár 88 tiszti beosztásából 58, a 23 tiszthelyettesi beosztásából 12 volt feltöltve. Különösen a szakaszparancsnoki posztok betöltése jelentett gondot, 31 beosztásból mindössze ötöt sikerült feltölteni, a többibe tartalékos tiszteket ${ }^{83}$ és tisztjelöltek helyeztek. Ennek következtében a katonai kiképzés akadozott, a századparancsnokokat túlterhelték a létszámgondok.

81 Közúti jármüvek részére viszonylag egyszerü pontonos híd létesítése egy folyón, viszont vasúton sokkal több árut lehet elszállítani, ezért a néphadsereg müszaki tisztjei a MAHART és a MÁV szakemberei egy gyorsan telepíthető vasúti híd tervét dolgozták ki. A MAHART tulajdonában lévő 1600 tonnás TS uszályokat úgy alakították át, hogy a 6 darab 80 m hosszú uszályt merőlegesen a sodrásirányra rögzítették egymáshoz és a mederhez, majd két végükön egy csatlakozó elemmel kapcsolódtak a kiépített vasúti vágányokhoz. A Duna jobb partján Dunaújváros-Dunapart állomástól építettek a vasútépítő katonák pályát, a bal parton Szalkszentmárton állomásból ágaztatták ki a vonalat. Ez utóbbi megépítését a Néphadsereg címü hetilap úgy interpretálta, hogy a katonák iparvágányt építettek egy Dunamenti kavicsbányához. Néphadsereg. 1978 ápr. 22. 11. A vasúti uszályhidat 1977 szept. 24-én és nov. 30-án is öszszeállították Varsói Szerződés és a sajtó meghívott képviselői előtt. Magyar Ifjúság. 1977 szept. 30. 5.; Néphadsereg. 1977. okt. 1. 6.; Népszabadság. 1977. dec. 4. 5.; Haditechnikai Szemle. 1977/3. 75-76. és 1978/3. 81-85.

82 HL MN f. 2342/27/80.

83 Tartalékos tiszteket általában három hónapra hívták be, az első néhány napban kaptak egy gyorsított tanfolyamat, majd a maradék időre kihelyezték őket az alakulatokhoz, rendszerint szakaszparancsnoki beosztásban. A közlekedési dandár az általam vizsgált korszakban folyamatosan küzdött létszámhiánnyal, nem csak a hivatásos állománynál, hanem a sorkatonai állománynál is, köszönhetően az egyre több egészségügyi vagy szociális okból történő leszereléseknek. 
A vállalatok eleinte szkeptikusan viszonyultak a katonai munkaeröhöz, nem hittek hatékony alkalmazásukban. Más alakulatok katonái lenézték az új kiképzési rendszerü katonákat, az első kiképzési időszakban több durvaságot is elkövettek az Ercsibe helyezett 151. közúti zászlóalj katonáival szemben az ottani 37. forradalmi ezred öreg katonái, polgári alkalmazottak pedig többször is leitatták a zászlóalj katonáit - áll Mák Lajos örnagy, zászlóalj parancsnokának évértékelö jelentésében. ${ }^{84} \mathrm{~A}$ kezdeti gondok megoldásához és a napi teendök olajozott müködéséhez 2-3 évnek is el kellett telnie, mire egy-egy zászlóalj megfelelő szintet ért el mind az önálló gyakorlati szakkiképzésben, mind mozgósítási feladatok ellátásakor. Maga a dandár összekovácsolódása is több évig tartott, 1965 októberi jelentésében Hersiczky vezérőrnagy szerint még legalább 2-3 évre volt szükség, hogy a dandár megfeleljen a kívánt szintnek. ${ }^{85}$ A nehéz kezdés ellenére az építő alakulatok hamar népszerüvé váltak, ezért 1970-ig folyamatosan alakultak meg újabb zászlóaljak, illetve gyarapodtak századokkal. A zászlóaljak alá tartozó századok általában egyesével, legfeljebb kettesével kerültek széttelepítésre az ország egész területén a gyakorlati szakkiképzés idejére, kivéve a Budapest-Győr fóvonal új nyomvonalra való helyezésén dolgozó 156. zászlóaljat, itt olykor 3-4 százada is Bicskén települt. Szintén kivétel volt a 152. közúti zászlóalj, amely a hetvenes években föleg a fövárosban és környékén dolgozott.

1972-ben a dandár átkerült a Magyar Néphadsereg Müszaki Főnöksége alól a Magyar Néphadsereg Hátországi Alakulatok Parancsnoksága alá, amit a következő évben Hátországvédelmi Parancsnoksággá szerveztek át, a hátországvédelemben részt vevő összes fegyveres szerv munkájának összehangolására és a hátország fegyveres védelmének egységes irányítására. A kijelölt csapatok átvételéröl készült 1972. november 23-i jelentés szerint 150. dandár feladatát kívánatos volna a kiképzés szintjéhez, képességeihez igazítani, ugyanis az egység nem képes másra (például magasvízi híd építésére), csak út- és vasútépítésre, illetve helyreállításra. Kiképzési feladatait a vállalatoktól kölcsönzött eszközökkel látja el. „, Tapasztalható, hogy a hivatásos állomány az elöző évek során kialakult szemlélet következtében több helyen lebecsüli a katonai kiképzést, a harckészültségi és ,"M” feladatok jelentőségét. A kiképzés nem biztositja eléggé a katonák kellö színvonalú felkészitését $a z$ „,M" esetén várható feladatokra." ${ }^{86}$ A tárcaközi megállapodás érdemben nem módosította az alegységek feladatait, 1974-ben még mindig heti 51-55 órát dolgoztak a katonák, így nem maradt elég idő a katonai feladatok gyakorlására és továbbképzések megtartására ${ }^{87}$

A dandár első kinevezett parancsnoka Baranyák Sándor alezredes volt 1964. július 1-től 1968. szeptember 30-ig, ${ }^{88}$ őt Michel Miklós alezredes, később ezredes követte a poszton, aki a dandár felállításától kezdve részt vett a törzs munkájában. 1976. október 15-én Gál Miklós ezredes vette át a dandár irányítását, Michelt leváltották elöljárói hatalommal való többszöri visszaélés miatt és áthelyezték Budapesti Helyőrség Parancsnokságra osztályvezetőnek. ${ }^{89} \mathrm{~A}$ dandár felállításakor egy közúti (151.) zászlóalj, két vasúti (153. és 155.) zászlóalj, valamint egy

84 HL MN f. 5822-5828/80. 151. zlj. 45/1964. parancs.

85 HL MN f. 3273/27/81.MN Müszaki Főnök előterjesztése a 150. dandár helyzetéről a HM Titkárság részére.

86 HL MN f. 2200/199/84. Hátországi Alakulatok Parancsnokának jelentése az MNVK főnökének a kijelölt alakulatok, szervek átvételének végrehajtásáról.

${ }^{87}$ HL MN f. 10637/199/84. Jelentés a Hátországvédelmi Alakulatok Parancsnokságának alárendeltjei részére 1974. április 17-én és 24-én tartott vezetői értekezletről.

88 HL MN f. 3410-3414/83. 150. ddr. 57/1968. parancs.

89 Michel Miklós tiszti személygyüjtő anyaga. Honvédelmi Minisztérium Központi Irattára. Honvédeket foglalkoztatott saját építkezésén. 
önálló vonalépítő század (157.) tartozott az egységhez. 1965-ben egy közúti zászlóaljjal (152.) bővült a dandár, egy év múlva egy-egy közúti (154.) és vasúti (156.) zászlóalj került felállításra, a vonalépítő századot pedig zászlóaljjá szervezték át. Az utolsó új zászlóalj (158.) megalakítására 1969-ben került sor, elsősorban vasúti műszaki zászlóalj volt, de egyik százada útépítéseken dolgozott. 1972-ig maradt fenn ez a szervezeti rendszer, ekkor megszüntették a 152. zászlóaljat, számozását és rejtőszámát átvette az utolsóként létrehozott zászlóalj. ${ }^{90}$ 1974-ben feloszlatták a 154. közúti zászlóaljat is, ezután 1980-ig már nem változott a dandár szervezeti felépítése. 1972-ben a 151. közúti zászlóaljnál állítottak fel először kísérletképpen fegyvernélküli szolgálatot ellátó szakaszokat. ${ }^{91}$ Egy-egy századot általában 130-150 fő dolgozó honvéd és 6-8 kisegítő szolgálatot ellátó katona alkotott a hivatásos állományon kívül. A századok létszámtól függően négy, 40-50 fós szakaszokból álltak.

A hadsereg közlekedésfejlesztésében végzett jelentőségének elismeréseképpen írt Rödönyi Károly közlekedési és postaügyi miniszter levelet az új kiképzési rendszerü alakulatok felállításának tízéves évfordulója alkalmából 1974. szeptember 20-i keltezéssel; „,Ezúton mondok köszönetet azért a jó munkáért, melyet az elmúlt 10 évben a közlekedés és híradás épitése területén végezték. ... Az Önök munkája nagyban segiti a közlekedés elött álló célkitüzéseknek megvalósitását. Kérem Önöket, hogy az elkövetkezendö idöszakban is ugyanolyan lelkesedéssel, odaadással segitsék a közlekedés és hírközlés munkáját, mint eddig. "92

A zászlóaljaknál a december végi, január eleji bevonulással kezdődött az élet. A második évüket töltők összevonásra kerültek, hiszen más katonai kiképzést kaptak, mint az újoncok. Az alapkiképzés minden év januárjától február végéig tartott, március első hétfőjén kezdődött meg a gyakorlati szakkiképzésnek nevezett népgazdasági munka. Az elsőévesek a katonai és müszaki alapismereteket sajátították el. Az itt szolgáló sorkatonáknak gyakorlatilag két hónap alatt kellett elsajátítaniuk azokat az ismereteket, amikre a többi alakulatoknál szolgálóknak 8-12 hónap jutott. Bár a szombat délelőttök is rendelkezésre álltak a katonai kiképzésre, ezek vagy munkával, vagy politikai foglalkozással teltek. Másodvonalbeli alakulatokként elavult lőfegyverzetet kaptak, 1967-ben a frissen megalakuló 156. zászlóalj sorállományát II. világháborúban is használt szovjet típussal, a 44M karabéllyal szerelték fel. A 151. zászlóalj még 1969-ben is ilyen lőfegyverrel volt felszerelve. ${ }^{93}$ A másodévesek a katonai kiképzés keretében katonai müszaki ismereteket tanultak, valamint bővítették katonai ismereteiket. Ilyen volt a közúti alegységeknél a különböző burkolatú utak alapozása, szegélykövezése, koptatórétegek beépítése kézi és gépi erővel, kisebb mütárgyak javítási és korszerüsítési munkafolyamatainak ismertetése. Ezen kívül megismerkedtek különböző müszaki gépek adataival, alkalmazási területeikkel, illetve kezelésük elvi alapjaival. Az aszfalt- és betonburkolat előállításának technológiáiról és folyamatairól, valamint az utak csatornázási és vízelvezetési munkáiról is kaptak oktatást. ${ }^{94}$ Vasútépítő katonák vasúti alapfogalmakkal, vágányfektetési feladatokkal és módszerekkel ismerkedtek, amiket a

\footnotetext{
90 A 158. zlj a 152. zlj helyére települt, annak személyi állományának egy részét is átvette. Fedőszámok: 150 . ddr $=\mathrm{MN}$ 3705, 151. $\mathrm{zl}=\mathrm{MN} 1205,152 . \mathrm{zlj} .=\mathrm{MN} 1333,153 . \mathrm{zlj} .=\mathrm{MN} \mathrm{4518,154.zlj.}=\mathrm{MN} 1366,155 . \mathrm{zlj} .=\mathrm{MN} 5320,156$. $\mathrm{zlj} .=\mathrm{MN} 1737,157 . \mathrm{zlj} .=\mathrm{MN} 6050,158 . \mathrm{zlj} .=\mathrm{MN} 8381$.

91 Hargittai. 195. Megjegyzés: Halassy-Kürtösnél 1977 szerepel fegyvernélküli szolgálatra bevonuló szakaszok szervezési dátumaként, de ott nem jelölik meg pontosan melyik alakulatról van szó. 394.

92 HL MN f. 9405-9411/84. 152. zlj. 45/1974 számú parancs.

${ }^{93}$ HL MN f. 5929-5937/80. 156. zlj. 2/1967. számú parancs és 2994-2300/83.151. zlj. 5/1969 számú parancs.

94 HL MN f. 5267-5268/82. 151. zlj. 2/1965 parancs.
} 
századok által létrehozz úgynevezett müszaki gyakorlókertekben gyakoroltak. ${ }^{95}$ Mindkét zászlóalj típusnál közös gyakorlat volt a másodévesek kiképzésénél robbantás, műszaki zár és rombolt hidak, utak, vasutak helyreállítása és építése. Szeptember-október folyamán a zászlóaljak tisztesi iskolára írattak be századonként 15-20 honvédet, és nagyjából hasonló nagyságrendben írattak be sorkatonákat vasúti/közúti előmunkás tanfolyamra. A foglalkoztató vállalatokkal együtt szerveztek gépkezelöi és elömunkás tanfolyamokat, melyet összevontan tartottak meg egy-egy zászlóaljnál, a tanfolyam ideje egy és két hónap között változott, függően a képzés jellegétől. Általában ősszel zajlottak az előmunkás tanfolyamok, míg a nehézgépkezelői tanfolyamok a téli kiképzés alatt történtek, kizárólag másodéves sorkatonáknak.

A katonák elhelyezése függött a beruházási program hosszától. Ahol rövidebb, néhány éves időtartammal számoltak a vállalatok, ott ERDÉRT fabarakkokban helyezték el a katonákat, ${ }^{96}$ illetve a vasútnál pályafenntartási laktanya kocsikban is történt egy-egy század elhelyezése, mint például Pécsbánya-rendező pályaudvaron, ahol 3 ideiglenes vágányt és a szükséges közmücsatlakozásokat kiépítve állították be a laktanya kocsikat. ${ }^{97}$ A hosszabb alkalmazási idő esetén a MÁV típustervek alapján többszintes téglaépítésü épületeket emelt, amelyeket a honvédségi használat után saját üzemi célra, vagy lakóépületté átalakítva hasznosított. ${ }^{98}$

Munkaidő alatt tisztek és tiszthelyettesek $60 \mathrm{M}$ gyakorlóruhát hordtak, a sorállománynak munkaruha volt előírva - ez használt gyakorló ruházatot jelentett, amit kopottsága, szakadtsága miatt már nem lehetett egyenruhaként használni. Szabadidőben és laktanyai foglalkozásokon a sorállomány is $60 \mathrm{M}$ gyakorlót viselt, eltávozásra, szabadságra vagy más célból történő utazásra csak kimenő öltözetben mehettek el a sorkatonák, aminek viselése alól a századparancsnokok adhattak felmentést - hasonlóan a Néphadsereg összes alakulatához. Sorállomány számára első szolgálati évben 8 nap, második évben honvédeknek 10 nap, tiszteseknek 12 nap szabadság járt, illetve rendkívüli alkalmakkor -gyermek születésekor, házasságkötéskor, közeli rokon temetésekor- adhatott a századparancsnok előterjesztésére a zászlóaljparancsnok szabadságot. ${ }^{99}$

Sorkatonák fizetése a kitüzött feladatok százalékos teljesítési arányában emelkedett, ennek alapján 15-35\% jutalmazásban részesültek. 35\%-os jutalom a 100\% vagy afeletti munkateljesítmény után járt. ${ }^{100}$ Átlagosan 300-500-800 forintot kaptak kézhez havonta a katonák jutalomként, ahogy emelkedtek a bérek és a katonák teljesítménye. ${ }^{101} \mathrm{~A}$ kisegítő állományú sorkatonák - írnokok, egészségügyisek, cipészek, szakácsok - illetményük 18-20\%-át kapták kézhez. Éves prémiumban is részesedtek a katonák, általában a nyári hónapokban fizették ki az előző évi részesedést. Gyakorlati szakkiképzéskor napi 17,60 Ft volt az élelmezési kiszabat egy före, ez a hetvenes évek végére felment $28 \mathrm{Ft} /$ fö-re. Szocialista versenymozgalmakban való részvételért, szocialista szerződés kötéséért, élenjáró illetve kiváló katona cím elnyerésért is járt pénzjutalom egyéb

\footnotetext{
95 HL MN f. 9707/82. 156. zlj. 1/1966 szolgálati használatú parancs.

${ }^{96}$ MÁV Arch. LV. 10039. d. 100169/1970. Váci honvéd felvonulási telep bővítése; LV. 11624. d. 113964/1979. Martonvásári katonai telep megvásárlása.

${ }^{97}$ MÁV Arch. LV. 10152. d. 119918/1970. Pécsbányarendezőn honvédségi felvonulási helyszínrajz jóváhagyása.

98 MÁV Arch. AC. 11214. d. 4211/1970. Honvédségi felvonulási típusterv jóváhagyása., LV. 12710. d. 114071/1976. Apafa katonai felvonulási telep beruházási engedélyokiratának módosítása., AG. 14923. d. 5240/1977. HM telepek kialakításával kapcsolatos együttmüködési megállapodás.

99 HL MN f. 150-152/80. 150. ddr. 9 és 7/1964. parancs.

${ }^{100}$ Hargittai. 182.

${ }^{101}$ Hargittai. 184.
} 
kedvezmények mellett, ezek összege 200-500 forint között változott. A rossz szociális körülmények között élő sorkatonák 1969-től egyszeri leszerelési segélyben részesülhettek, ha legalább egy év szolgálati idejük megvolt, és nem volt érvényes fenyítésük leszereléskor. HM-BM 50/1969 számú parancs és az MN Pénzügyi Fönök 60/1969 utasítása alapján a leszerelésre kerülő sorállomány egyszeri pénzjuttatásának elbírálásához bizottságot kellett felállítani, ami döntött az egyes katonák részére kifizetendő segély mértékéről, ami 1000 és 3000 forint között változott. ${ }^{102}$

A katonákat igyekeztek a polgári dolgozóktól elkülönítve alkalmazni, lehetőleg század vagy szakasz erővel. A munkafolyamatokat vasúti előmunkás vagy pályafenntartási szakember, illetve építésvezető irányította, ha nem volt kellően szakképzett sorkatona egy adott munkánál. A megalakuláskor kitüzött cél azonban - teljesen önálló tevékenység - sosem valósult meg. Század nagyságrendủ munka 8-12 km vonalhosszra terjedhetett ki, szakasz erejủ egységet legfeljebb 2-3 átereszen való munkálatokra, vagy 5-6 km nyílt vonali szakasz munkálataira vezényelhettek - az elöírások szerint, ezt persze gyakran nem sikerült betartani, különösen az első években. Közúti alegységekre is a fenti elöírások vonatkoztak, azzal a kiegészítéssel, hogy szakasz nagyságú munkahelynek számítottak a közúti felüljárók, gyalogos aluljárók, egyedi vagy közúti hidak és a központi elöregyártó telepek. ${ }^{103} \mathrm{~A}$ dandár tartott kapcsolatot a MÁV Építési és Pályafenntartási szakosztályával, az Aszfaltútépítő, Betonútépítő, a Közlekedési Építő és a Hídépitő vállalatokkal, illetve ezek építési fönökségeivel. A zászlóaljak az építési fönökségekkel, főépítés vezetőségekkel és az építésvezetőségekkel, míg a századok az építésvezetőségekkel egyeztettek, legalsó szinten pedig a szakaszok a müvezetőkkel. ${ }^{104}$ A katonák munkateljesítménye elérte a polgári munkavállalók teljesítményét. A baleseti jegyzőkönyvekből derül ki a legjobban, hogy milyen jellegü munkákat végeztek a katonák. Minden reggel, munkakezdés előtt balesetvédelmi oktatást tartott az előmunkás vagy müvezető az aznapi feladathoz kapcsolódó veszélyforrásokról. Legalábbis elméletileg, mert 1969-ben igen sok baleset történt, ami a MÁV vizsgálata szerint egyszerre volt a müvezetők, pályamesterek hibája az elhanyagolt balesetvédelmi oktatások miatt, valamint a honvédeké a hanyag munkavégzés okán. ${ }^{105}$ Munkahelyi sérülések legtöbbször emberi mulasztásból, gondatlanságból következtek be, az 1972-1973-as év jegyzökönyvei között a csonttöréses és zúzódásos balesetek domináltak a munkahelyen szerzett sérülések okai között. Előfordultak súlyosabb balesetek is, néha halálesetek is, azonban arányuk jóval kisebb volt az ittas állapotban elszenvedett súlyosabb balesetekhez, illetve öngyilkosságokhoz és öngyilkossági kísérletekhez képest.

Milyen munkát végeztek a katonák? Gyakorlatilag minden munkafolyamatot meg tudtak oldani kellő müszaki irányítással, ha katonák között volt müszaki végzettségü ember, akkor vállalati művezetői irányításra sem volt szükség. Megszabott feladatoknak megfelelöen törtek betont, szegélykövezést végeztek, a gépkezelői tanfolyamot végzettek akár úthengert és aszfaltfinishert is vezettek, földmunkát végeztek. A vasútépítők vágányt bontottak és fektettek, síngombolást végeztek, ágyazat rendezést végeztek, krampácsoltak, sínt hegesztettek, valamint pályaépítő és karbantartó gépeket szolgáltak ki. ${ }^{106}$

\footnotetext{
${ }^{102}$ HL MN f. 3415-3423/83. 151. zlj 8/1970 számú parancs.

${ }^{103}$ HL MN f. 4162-4169/84. 153. zlj. 14/1973 számú parancs és 4264-4270/84. 151. zlj. 16/1974 számú parancs.

${ }^{104}$ HL MN f. 1556-1562/83. 150. ddr. 10/1969 számú parancs.

${ }^{105}$ MÁV Arch. AG. 12645. d. 6477/1970. Honvédségi alakulatoknál a személyi balesetek helyzete.

${ }^{106}$ HL MN f. 1976. 41. d. 136. és 148. őe. 150. ddr. baleseti jegyzőkönyvei 1972-1973.
} 
A század és szakaszparancsnokok a szakmai irányításba nem szólhattak bele, nem állíthatták le a munkát, nem helyezhettek át személyeket, szakmai irányításért a megbízott polgári személyek feleltek. Az alegységek parancsnokai csak a katonai és a munkafegyelemért, valamint a kiadott munka végrehajtásáért feleltek, észrevételeiket és kifogásaikat az elöljárónak kellett jelenteniük. A századparancsnokoknak ismerniük kellett a foglalkoztató építésvezetőségek feladatait, szervezetét, anyagellátási rendszerét, elszámolási rendszerét, az építésvezető jogait és kötelességeit a kivitelezés folyamán, illetve az alegységre vonatkozó konkrét munkavédelmi elöírásokat. Szakaszparancsnokoknak a kivitelezési munkák időnormáit, módszereit, fogásait, szervezési elveit, munkafolyamatok megnevezését és technológiáját, valamint az elszámolás módját kellett elsajátítaniuk a normakönyvek alapján. Természetesen a szakasz munkavégzésére vonatkozó munkavédelmi elöírásokkal is tisztában kellett lenniük. ${ }^{107}$

Az általam vizsgált időszak alatt az elkövetett fegyelmezetlenségeket és büncselekményeket az esetek túlnyomó többségében alkoholos befolyásoltság alatt követték el. Az alkoholizmus és túlzott szeszfogyasztás nemcsak a sorkatonák, hanem a hivatásos tiszthelyettesi és tiszti állománynál is súlyos gondokat okozott. A sorkatonák fizetésük egy részét rendszeresen italra költötték, bár a nagyját takarékbetétbe helyezték - nem saját szorgalomból, hanem az italozás visszaszorítása illetve büncselekmények megelözése végett takarékbetétbe helyezték a századparancsnokok. Sorkatonák fenyítése általában kimenő megvonása volt 2-4 hétre (laktanyafogság), illetve jutalom megvonását alkalmazták. Következő szint a helyőrségi fogda 5-30 nap közötti időterjedelemben, súlyosabb esetekben, mint például több napig tartó engedély nélküli távolmaradás, függelemsértés, lopás vagy parancsmegtagadás esetén minimum 3 , maximum 24 hónapra fegyelmező zászlóaljhoz küldték a fenyített sorkatonát. ${ }^{108}$ A vizsgált időszakban Rákospalotán volt a hadsereg központi fegyelmező zászlóalja. Civilekkel szemben elkövetett súlyosabb cselekményekért valamint föben járó katonai vétségekért, mint például szökési kísérlet, a hadbíróság azonnali leszerelést és legalább két év fogva tartást ítélt. A fegyelmező zászlóaljba való „,beutalás” is már hadbírósági jogkör volt, egységparancsnok legfeljebb helyőrségi fogdát szabhatott ki a bünösre. A hivatásos állományt a kemény és szokatlan munka, valamint a családtól való elszakítottság taszította az alkohol mámorába. Több tiszt is panaszolta, hogy nem kapott lakást munkahelyéhez közel, ezért 2-4 hetente tudott csak hazautazni, emiatt magánéleti problémája is támadt néhányuknak, ami egy-egy esetben kihatott a szolgálatra is. Fenyítéseknél második leggyakoribb ok a katonai szabályzat nem kellő betartása, különböző feladatok, rendkívüli események jelentésének késedelmes végrehajtása volt. Előkelő helyen szerepelt még a lopás és sikkasztás, az elöljárói hatalommal való visszaélés, amikor a tisztek saját célból dolgoztattak sorkatonákat, például házépítésen, garázsépítésen, lakásfelújításon, gyakran honvédségi anyaggal való visszaéléssel egybekötve. Általában ez utóbbit nem vizsgálták annyira szigorúan, csak ha már többször is botlott az illető. Különböző fegyelemsértések, szabálytalanságok és büncselekmények elkövetése miatt lefokozásra és hadseregből való elbocsátásra ítélt tisztek és tiszthelyettesek száma a rendelkezésre álló iratok szerint 30 fő körül lehetett 1964 és 1977 között.

Sok tiszt számára szokatlan volt a beosztás, amit el kellett látniuk, még akkor is ha müszaki tiszti iskolát vagy tanfolyamot végeztek. A 155. zászlóalj parancsnoka Lőczi József alezredes,

\footnotetext{
${ }^{107}$ HL MN f. 5202-5205/79. 153. zlj. 34/1964 számú parancs. és 888-899/85. 156. zlj. 41/1975 számú parancs.

${ }^{108}$ Ezt hívták bakaszlengben „futkosónak”. Az itt töltött idő nem számított bele a sorkatonai időbe.
} 
beosztott századparancsnoka, Nyerges József őrnagy, valamint a 153. zászlóalj parancsnoka Horváth József alezredes, és beosztott századparancsnoka, Serák József örnagy rendelkezett vasútépítési illetve vasútforgalmi ismeretekkel világháborús tapasztalatok illetve polgári előéletükből. Más tisztek nem rendelkeztek komolyabb előzetes ismeretekkel sem a vasútépítés, sem az útépítés terén. Feladatuk ellátása érdekében a tiszteknek el kellett sajátítaniuk alakulatuk profiljába tartozó müszaki alapismereteket is. Tovább nehezítette a tisztek -elsősorban a századparancsnokok- helyzetét az egyre nagyobb tiszt- és tiszthelyettes hiány. A betöltetlen beosztások és a hivatásos állomány csökkentése végett bevezették a sortiszthelyettesi rendszert. A 150. dandár 1974 öszén 121 rendszeresített tiszthelyettesi beosztással rendelkezett, azonban csak 58 hivatásos és 26 továbbszolgáló tiszthelyettes szerepelt az állománytáblán, vagyis a beosztások mindössze $61 \%$-a volt feltöltve. 37 fó hiányzott a rendszerből, ezt 35 sorállományú tiszthelyettesi beosztásba való kinevezésével orvosolták, ebböl 4 fő kiképzés után, 31 fő pedig központi tanfolyam nélkül lett kinevezve. ${ }^{109}$ A zászlóaljparancsnokokra alakulatuk országszerte való széttelepülése rótt pluszfeladatokat és felelősséget, sokkal nehezebb volt így irányítani az alegységüket, mint a hagyományos fegyvernemi alakulatoknál. Ezek után nem lehet csodálni, hogy több tiszt 55 éves kora előtt került nyugállományba, vagy kérte nyugállományba helyezését az egészségügyi felülvizsgálaton kapott békében alkalmatlan minősítéssel, leszázalékolva. Michel Miklós dandárparancsnok 1974 áprilisában kérelmezte elöljárójától a tárcaközi megállapodások felülvizsgálatát, mivel az alakulatokhoz beteg tisztek kerültek, akik már nem bírták a feladatokat maradéktalanul ellátni. ${ }^{110}$

Felmerülhet a kérdés, vajon nem büntetésböl helyeztek át tiszteket a közlekedési dandárhoz? A hozzáfért iratok alapján ezt nem lehet egyértelműen kijelenteni, bár nem sikerült az összes tiszt személyi iratát átnézni. Két esetben történt büntetésböl az áthelyezés, egy esetben pedig valószínüsíthető a büntető célzat. Az viszont több tiszt személyi anyagában is előfordul, hogy az alacsonyabb végzettségü, katonai ismereteik terén problémás, gyengébb képességü tiszteket áthelyeztették a közlekedési dandárhoz. Érdekes módon több ilyen tisztnél is pozitív változás történt az áthelyezés után a minősítések szerint. Maga a fizetési rendszer, a jutalmak mértéke és gyakorisága is árnyalja a képet. A tiszti fizetés több részből tevődött össze; beosztási illetmény, rangfokozati illetmény, a szolgálati évek utáni százalékos kiegészítés mellett még családi pótlék valamint nyelvvizsga pótlék illette meg őket, ez utóbbit persze csak kevesen kaptak. A jobb munkavégzés ösztönzésére a hivatásos állománynál is létezett teljesítményjutalom, a vezető állomány az alegységük, átlagkeresetének 30-35\%-át kapta kézhez az 1971-ben lépett életbe rendszer szerint, majd 1973-ban a vezetők részesedését 40-60\%-ra emelték. Természetesen éves részesedési jutalmat is kaptak, valamint év végén a honvédelmi miniszter parancsára külön jutalomban részesültek azok, akiknek nem volt érvényes fenyítése, valamint a foglalkoztató vállalatok is adományoztak időnként pénzjutalmat egy-egy tisztnek valamilyen fontosabb munkafázis eredményes, gyors elvégzéséért.

A KPM részéről csak egyetlen iratot találtam, ami valamelyest rávilágít az új kiképzési rendszerü alakulatok megítélésére a foglalkoztatói oldal szemszögéből. Az Országos Tervhivatal X. Építkezési Főosztálya kért adatszolgáltatást a KPM-nél alkalmazott katonai munkaerő építési

${ }^{109}$ HL. MN f. 10638/199/84. Tájékoztató jelentés a sortiszthelyettesi rendszer bevezetése terén eddig végrehajtott feladatokról, tapasztalatokról.

${ }^{110}$ HL MN f. 10637/199/84. Jelentés a Hátországvédelmi Alakulatok Parancsnokságának alárendeltjei részére 1974. április 17-én és 24-én tartott vezetői értekezletről. 
teljesítményéröl. A KPM szerint a katonák munkateljesítményét nem lehet elkülöníteni a polgári dolgozókétól, nem akadt kirívó különbség sem pozitív, sem negatív irányban. Az AUV gárdonyi és polgárdi munkahelyein 100,5\% ill. 101,8\%-os teljesítményt nyújtottak a katonák. A félévi összegzés szerint az állomány szakmai összetétele általában nem kielégítő, föleg a nehéz fizikai munkák miatt. A vasútépítő katonák ${ }^{111}$ munkaintenzitása jó, jó minőségű és kedvező mennyiségü munkaerőt nyert a vasút ezekkel a zászlóaljakkal, összesen több mint 55 millió forint értékben termelt a vasútnál átlagosan foglalkoztatott 643 fó, átlagos munkateljesítményük 101\%-on alakult.

A Közlekedési Építő Trösztnél történő munkavégzésben 492 fő vett részt a müszaki alakulatoktól, és a KÉV „K” munkáján 161 katonát foglalkoztattak, összesen tehát 653 föt. Munkateljesítmények a következőképpen alakultak, a BUV-nál 93,2\%, az AUV-nál 95,6\%, a Hídépítő Vállalatnál $96,6 \%{ }^{112}$

5. táblázat: 150. dandár 1965 I. félévi teljesítménye

\begin{tabular}{|l|c|c|c|c|c|c|}
\hline & $\begin{array}{c}\text { Termelési } \\
\text { érték, } \\
\text { ezer Ft }\end{array}$ & $\begin{array}{c}\text { Átlagos } \\
\text { létszám }\end{array}$ & $\begin{array}{c}\text { Átlagos } \\
\text { normateljesítés, } \\
\%\end{array}$ & $\begin{array}{c}\text { Kifizetett } \\
\text { jutalom, } \\
1000 \mathrm{Ft} .\end{array}$ & $\begin{array}{c}\text { Elszámolt } \\
\text { költség a } \\
\text { HM-nek, } \\
1000 \mathrm{Ft}\end{array}$ & $\begin{array}{c}\text { Elszámolt } \\
\text { költség a } \\
\text { HM-től, } \\
1000 \mathrm{Ft}\end{array}$ \\
\hline KÉT & 45.500 & 653 & $82,9-96,6$ & 979 & 6.664 & 403 \\
\hline MÁV & 55.350 & 643 & 101 & 1113 & 4.631 & 320 \\
\hline Összesen & 100.850 & 648 & & 2092 & 11.295 & 723 \\
\hline
\end{tabular}

A dandár történetének és tevékenységének teljeskörü rekonstrukciója a jelenleg rendelkezésre álló iratok alapján egyelőre nem lehetséges, a bevezetőben már említett forráshiányok miatt. Nehézséget okoz sokszor az egyes munkahelyek azonosítása is, különösen a közúti zászlóaljak esetében. Nagyon kevés tájékozódási pontot említenek az iratok, hogy az egyes századok és szakaszok mit, hol és meddig csináltak. A vasúti alegységek munkahelyeinek feltérképezése valamivel könnyebb, a vasútvonalak és vasútállomások segítenek a lokalizálásban. Néhány napi parancsban fennmaradt a katonák konkrét munkavégzése, azonban a legjobb forrás erre baleseti jegyzőkönyvek, amikben pontosan leírják a baleset helyét, körülményeit, és gyakran egy-egy munkafolyamatot is. Sajnos csak 1972-73-as évek baleseti jegyzőkönyvei maradtak fenn a dandár összes alakulatától, a 151., 153., 155. és 156. zászlóaljak baleseti jegyzőkönyvei is véletlenszerüen örződtek meg.

\section{KöZÚTÉPÍTő zÁSZLÓALJAK}

Közútépítő alegységek közül elsőként a 151. közúti zászlóalj (MN 1205) alakult meg 1964-ben Mák Lajos őrnagy irányításával Kalocsán egy burkolatépítő, egy alépítményépítő és egy hídépítő századdal, ezek létszáma eltérő volt. 1969 augusztusban Macher Ferenc őrnagyot nevezték ki

\footnotetext{
${ }^{111}$ Bakaszlengben a vasútépítésen dolgozó honvédokat „Sínhuszárnak” vagy „Krampácsbercinek” nevezték. http:// mnytud.arts.klte.hu/sorozat/katszl/index.html Hozzáférés: 2021.07.12.

${ }^{112}$ MNL OL XIX H-1-c. 32. d. 00333/1965. Az építőiparban foglalkoztatott müszaki alakulatok.
} 
zászlóaljparancsnoknak, miután Mák Lajost a dandártörzshöz helyezték át. ${ }^{113}$ Sajnos a kezdeti évek iratanyaga ennél az alakulatnál is eléggé hiányos, ráadásul a dandár iratai között is kevés információ található róla. Júliustól a 2. század Martonvásáron, a zászlóalj többi része Budaörsön települve kapcsolódott be a balatoni gyorsforgalmi út megépítésébe. Mivel a század elsősorban az M7 autópálya építésén és a 7-es foút balatoni szakaszának átépítésén dolgozott, így elsősorban a Betonútépítő Vállalat alkalmazásában állt. 1966-ban a hídépítő század Kápolnásnyéken települt. 1967-ben Székesfehérváron, egy évvel később már Polgárdiban települt a zászlóalj. ${ }^{114}$ 1968-ben kisebb botrányok történtek a zászlóaljnál a zászlóaljparancsnok körül. Baranyák alezredes értékelése szerint Mák alezredes munkavezetési stílusa durva, beosztottjait gyakran túlóráztatja és rossz viszony alakult ki politikai helyettesével, ezen kívül nemi eröszakot próbált elkövetni titkárnőjével. ${ }^{15}$ Ugyanakkor a zászlóalj rendszeresen megfelelő és jó értékelést kapott az éves értékelésekkor.

1969-ben két burkolatépítő századdal bővült az alakulat, ők április végén kapcsolódtak be a gyakorlati szakkiképzésbe, két régebbi század pedig Siófokra diszlokált. Az alegység feladata az autópálya Székesfehérvár-Zamárdi szakaszának építése volt a rajta lévő mütárgyakkal együtt. ${ }^{116}$ 1971-ben balatonőszödi kormányüdülőben zajló építkezésre volt vezényelve néhány katona. ${ }^{117} \mathrm{Az}$ M7 bal pályájának elkészültével a siófoki két század közül augusztusban egyet Martonvásárra telepítettek át a törzzsel és két polgárdi századdal együtt, míg a hídépítő század Siófokról előbb Polgárdiba, majd Budapestre a Szőnyi útra diszlokált és a kisföldalatti pályájának meghosszabbításában vett részt. A következő évben az első négy század az M7 jobb pályájának építésén dolgozott, burkolást, szegélyezést, utómunkálatokat és a keverötelepek kiszolgálását végezve. 1975-ben újra Polgárdiba települt át a zászlóaljtörzs, együtt haladva a jobboldali sáv építésével, a 4. és 5. századot viszont az Aszfaltútépítő Vállalat munkahelyére vezényelték az M1 gyorsforgalmi út Tata-Komárom szakaszának építésére. A 3. század két szakaszát Budapestre vezényelték, ahol az 1. szakasz a Közlekedési Építő Vállalat Deák téri metróépítkezésén, a 2. szakasz a Hídépítő Vállalat hegyalja úti BAH-csomópont ${ }^{118}$ munkahelyén került foglalkoztatásra. ${ }^{119} 1976$ iratai kutathatók az utolsó teljes évként. Az 1. század a 3. századdal együtt az $M 7$ autópályán végzett hídpótlási munkákat, és építési munkákat. Ezek befejezése után a BUV megbízásából részt vett a Mór-Balinka összekötö út építésében. 2. század Budapesten, a Szőnyi úton települt, 100 fővel a MOH-csomópontot ${ }^{120}$ építette a Hídépítő Vállalat irányításával, 50 fővel pedig a 3-as metró második szakaszán dolgozott a Határ útnál. A 3. század az M1 és M7 bevezető szakaszán dolgozott, Budaörsi települési helyről kiindulva, míg a 4. század Győrben lett elhelyezve, ahol 100 fövel az M1

\footnotetext{
${ }^{113}$ HL MN f. 1556-1562/83. 150. ddr. 55/1969 számú parancs.

${ }^{114}$ HL MN f. 5822-5828/80. 151. zlj. 5., 10. és 24./1964 számú parancsok; 5269-5273/82. 12/1966 számú parancs; 9645-9649/82. 2/1967 számú parancs; 9650-9652/82. 5/1968 számú parancs. Néphadsereg. 1964. dec. 5. 6., 1965. ápr. 17. 2. 1967. aug. 19. 6.

${ }^{115}$ HL MN f. 9639-9644/82.150. ddr. 16 és 24/1968 számú parancsok.

${ }^{116}$ HL MN f. 1556-1562/83. 150. ddr. 10/1969 számú parancs; 2994-9300/83. 151. zlj. 41, 67/1969 számú parancsok.

${ }^{117}$ HL MN f. 8778-8786/83. 151. zlj. 29/1971 számú parancs.

${ }^{118}$ Budaörsi út - Alkotás utca - Hegyalja út csomópont.

${ }^{119}$ HL MN f. 8778-8786/83. 151. zlj. 69, 84/1971 számú parancs, 4258-4263/84. 16/1973 számú parancs, 4271-4276/84. 6., 26., 59. és 83/1975 számú parancsok.

${ }^{120}$ Marx Károly út - Ócsai út - Haraszti út csomópont
} 
félautópálya mütárgyainak építésén, a győri Kis-Duna-híd építésén és az Ipar utcai felüljáró építésén dolgozott a Hídépítő Vállalat irányításával. 50 fővel a M1 félautópályán csomópont és mütárgyépítési munkákat végeztek a 108-118 km szelvényben az AUV megbízásából.

Az 5. század M1 autópályán hiánypótlási munkákat végeztek a 87-107 km szelvényben szakaszkötelékben, és építési munkákat a 87-117 km szelvényben. ${ }^{121}$

1965-ben hozták létre a 152. közúti müszaki zászlóaljat (MN 1333) Székesfehérváron Kovács Lajos alezredes parancsnoksága alatt három századdal. Mindhárom század az M7 autópálya építésén vett részt 1965 és 1967 júliusa között, ekkor az alegység Gödöllőre települt át. ${ }^{122}$ Az év végén Botka Mihály őrnagy került a zászlóalj élére és 1977-ig ő is maradt a zászlóaljparancsnok. ${ }^{123}$ 1968-ról nem maradt fenn információ a munkahelyekről, feltételezhetö, hogy a 3-as föút átépítésén dolgoztak a katonák Hatvan és Gyöngyös között. Közvetett adatok alapján feltételezhető, hogy a hídépítő század részt vett a 3-as főút gyöngyösi átkelési szakaszának áthelyezésében és a vasúti aluljáró megépítésében. ${ }^{124}$ Egy évvel később egy századdal bővült az alakulat. A 2. század Kápolnásnyékre települt át és újra bekapcsolódott a balatoni gyorsforgalmi út építésébe. A többi század Gödöllön maradt, innen jártak mindennap dolgozni a 3-as főút gödöllői szakaszának utómunkáinak befejezésére, a Baross tér átépítésére, Hungária körúti és a hatvani vasúti felüljáró építésére. Feltehetőleg a 3. század szakaszai dolgoztak Tatabányán, Budaörsön és Csepelen, valamint a Tatabánya-Bicske szakaszon az M1 gyorsforgalmi út építkezésén az Aszfaltútépítő Vállalat irányításával. 1971-ben az 1. és 2. század a Szentendrei HÉV Batthyány tér-Margit híd szakaszának átépítésén és a Kossuth tér-Déli pályaudvar metrószakasz építkezésén lettek foglalkoztatva, míg a 3. század a Csepel Gépgyár rekonstrukcióján, a 4. század pedig az M1 gyorsforgalmi út építésén dolgozott. ${ }^{125}$ 1972-ben az 1-3 századok a 2-es metró második szakaszán dolgoztak, míg a 4. század a Hungária körúti és a Jászberényi úti vasúti felüljárók építésén vett részt, a gépszakasz pedig a Dombóvári úton dolgozott a KÉV telephelyén. 1973 februárban a gödöllői századok és a törzs áttelepült Budapestre, megosztva a Külső-Váci úti és a Szőnyi úti objektumokba, a Nagyvárad téren már dolgoztak a katonák a 3-as metró építésén. Egy évvel később az egyik század dolgozott az Árpád úti vasúti felüljáró megépítésén. 1976-ban már az összes század Budapesten települt, hogy a helyi közúti építkezéseken, valamint a 3-as metró beruházásain dolgozzon. Az utolsó évről is kevés adat maradt fenn, a KÉV munkahelyein dolgoztak katonák a Dombóvári úti telephelyen, valamint Csepelen a Vasgyárnál és az ÁFOR telepnél. ${ }^{126}$ Júniusban a dandárparancsnok 66-5/1977 számú intézkedése a 3. század állománya számára komplex hídépítő gyakorlatot rendelt el Verpeléten. A Tarna-patak megrongálódott hídját kellett elbontani és helyébe új 60 tonnás, egypályás alacsonyvízi 29,5 m hosszú hadihidat építeni június 6-12-én. Ehhez kapcsolódott még 100 m út- és ároképítés június 18-19-én. 3 tiszt, 12

${ }^{121}$ HL MN f. 4277-4284/84. 151. zlj. 22/1976 számú parancs.

${ }^{122}$ HL MN f. 8012-8015/79. 152. zlj. 13/1965 számú parancs, 4526-4531/80. 9/1966 számú parancs; Néphadsereg. 1965. ápr. 17. 2.

${ }^{123}$ HL MN f. 7435-7440/80. 152. zlj. 58/1967 számú parancs.

${ }^{124}$ HL MN f. 6448-6454/82. 152. zlj. 43/1968 számú parancs; Vasút 1969/9. 4-5.

${ }^{125}$ HL MN f. 1556-1562/83. 152. zlj. 10/1969 számú parancs, 10616-10624/82. 152. zlj. 66/1969 számú parancs, 10404-10408/83. 20/1971. számú parancs; Néphadsereg. 1970. aug. 1. 2. és 7., 1971. márc. 4. 11., 1972. dec. 23. 10.

${ }^{126}$ HL MN f. 1086-1096/84. 152. zlj. 69/1972 számú parancs, 1601-1607/84. 150. ddr. 13/1973 számú intézkedés; Néphadsereg 1973. jún. 23. 7., 1974. ápr. 27. 8., 1976. febr. 14. 11. 
cölöpöző és 50 hídépítő sorkatona lett vezényelve Csécs Ferenc százados parancsnoksága alatt. A híd pótlása a megadott időhatárok között sikerült, ezért jutalomszabadságokat adományozott Botka alezredes néhány sorkatonának. ${ }^{127}$

Utoljára a dandár útépítỏ alegységei közül a 154. közúti zászlóalj (MN 1366) került felállításra 1966 végén Mikola János őrnagy parancsnoksága alatt. Végig ő irányította a zászlóaljat, annak 1974 eleji felszámolásáig, ekkor a 156. vasúti zászlóalj törzsfönöki beosztását kapta meg már alezredesi rangban. Több áttelepülés után végül 1967 áprilisában Győrbe települt a zászlóalj törzse és a 2-3. század a gépszakasszal együtt, az 1. század Ercsiben a 6-os foúton hajtotta végre a gyakorlati szakkiképzést. ${ }^{128} \mathrm{Az}$ alakulat az Aszfaltútépítő Vállalattal és a Győri Közúti Üzemi Vállalattal kötött szerződést, elsősorban a 1. számú foúton hajtott végre út és hídépítési feladatokat fennállása során. Még 1967-ben egy-egy szakasza Gödöllőn és Kápolnásnyéken, a 152. és 151. zászlóaljak alá rendelve dolgozott, a többi század Mosonmagyaróvár, Mosonszentmiklós, Öttevény és Komárom közelében tevékenykedtek. Egy év múlva az 1. és 3. század Győrben települt, a 2. század Székesfehérváron. 1969-ben az alakulat az 1-es föút komáromi, győri és mosonmagyaróvári átkelési szakaszain került alkalmazásra, Győrben hídépítésen is részt kellett vennie a 2. század egy részének. Egy évvel később Csornán, Pannonhalmán, Pápán, Ménföcsanakon és Győrben dolgozott a zászlóalj. A megyeszékhelyen a Magyar Vagon és Gépgyár területén végzett útépítést, illetve a Rába-hídon dolgoztak. ${ }^{129} \mathrm{~A}$ következő három évre már csak a dandár iratai között leltem adatokra, mivel a zászlóalj iratai csak 1970-es évig kutathatók. 1971-es évröl csak annyit lehet tudni, hogy botrány történhetett, mert a 33. dandárparancs szerint a 154. zászlóalj törzsében évek óta rossz a viszony parancsnok, a politikai helyettes és a törzsfőnök között. ${ }^{130} 1973$-ban a zászlóalj 4. százada Törökszentmiklósra diszlokált, ahol a 4-es föút rekonstrukciójában vett részt, az 1-2. századok Tatán települve hajtották végre szakkiképzésüket az M1 félautópálya építésén, míg a 3. század Győrben maradt. ${ }^{131}$

\section{VASÚTÉPÍTő ZÁSZLÓALJAK}

Időrendi és számozási sorrendben haladva a 153. vasúti müszaki zászlóalj (MN 4518) az első. 1964-ben hozták létre az alegységet, első parancsnokának Horváth László őrnagy lett kinevezve. A zászlóalj a MÁV celldömölki, budapesti és pécsi építési fönökségek területén dolgozott, 1970-ig a Szabadbattyán-Tapolca, a Szombathely-Hegyeshalom, a Székesfehérvár-Murakeresztúr és Székesfehérvár-Komárom vonalakon. ${ }^{132}$ 1967-ig harmadik százada a 155. zászlóalj alá volt rendelve, így az az egy század a MÁV szentesi építési fönökség területén dolgozott. Már 1964 decemberében négyhónapos nehézgépkezelöi tanfolyamra küldtek 29 föt és öthónapos munkavezetői tanfolyamra 15 föt. A következő évben a zászlóaljparancsnokot leváltották

\footnotetext{
${ }^{127}$ HL MN f. 4466-4471/87. 152. zlj. 15, 26, 29/1977 számú parancsok.

${ }^{128}$ HL MN f. 7233-7239/80.154. zlj. 17, 21, 33, 51, 59, 68/1967 számú parancsok.

${ }^{129}$ HL MN f. 1556-1562/83. 150. ddr. 10/1969 számú parancs; 3837-3842/83. 154. zlj. 32, 34, 42, 46/1969 számú parancsok, 8475-8481/83. 16, 25, 27/1970 számú parancsok

${ }^{130}$ HL MN f. 5839-5847/83. 150. ddr. 33/1971 szolgálati használatú parancs.

${ }^{131}$ HL MN f. 1601-1607/84. 150. ddr. 13/1973 számú intézkedés.

${ }^{132}$ Néphadsereg. 1965. szept. 25. 17.
} 
különböző botrányok miatt, ${ }^{133}$ helyére Horváth József alezredes került 1968. december 31-i nyugállományba vonulásáig. Ekkor Nagy László alezredes nevezték ki zászlóaljparancsnoknak, tőle 1973 májusától Simon Sándor alezredes vette át a beosztást. ${ }^{134}$ 1966-ban Zánkára települt át a törzs. 1969-ben negyedik századot is szerveztek az alegységhez, így mind a négy korábban felsorolt vasútvonalon egyszerre dolgoztak a katonák. ${ }^{135}$

1970-ben a tiszai árvíz levonulása után összesen 24 föt vezényeltek a zászlóaljtól a csengeri építkezésekre az év végéig, ebben az évben egyébként már Tapolcán települt a zászlóaljtörzs. ${ }^{136}$ 1970-1977 között folytatódott a munkavégzés a fenti szakaszokon, majd a Tapolca-Balatonszentgyörgy, Tapolca-Ukk-Boba, Dombóvár-Pécs, Dombóvár-Bátaszék, Dombóvár-Gyékényes és Pécsbánya-Villány vonalakon dolgoztak a katonák. Az 1967 óta Csornán települö századot 1971-ben áthelyezték Pécsbánya-rendezőre, hogy a Pécs-Magyarbóly vonal korszerűsítésében vegyenek részt. Szabó Béla szombathelyi vasútigazgató hiába kérte Rödönyi Károly MÁV vezérigazgatót, hogy a századot ne vezényeljék át, mert a század nélkül megáll a porpác-hegyeshalmi vonal átépítése. ${ }^{137} \mathrm{~A}$ zászlóalj részt vett a pécsi fóvonal abaligeti alagútjainak és a vonal áthelyezésének munkálataiban is. ${ }^{138}$ Mindezek mellett a balatonfüredi állomás építésénél is jelen voltak. ${ }^{139}$ Általában egy-egy század települt Csornán, Tapolcán vagy Balatonfenyvesen, és két század Pécsett vagy Dombóváron. 1972-ben öt századra bővült az alegység.

Szintén 1964-ben alakult meg a 155. vasúti müszaki zászlóalj (MN 5320) két századdal Lőczi József örnagy parancsnoksága alatt. 1970-ben Ökrös Lajos alezredes követte az alakulat élén, ${ }^{140}$ tőle Molnár László alezredes vette át a parancsnokságot a 155. és 158. zászlóaljak furcsa összeszervezésekor. ${ }^{141} 1975$ novemberéig töltötte be beosztását Molnár alezredes, betegség miatt őt Joó Zoltán alezredes váltotta a zászlóalj élén. A zászlóalj iratai csak 1966-tól maradtak fenn, korábbi eseményekre csak a dandár irataiból lehet információt nyerni, elsősorban a MÁV budapesti, szentesi, miskolci, debreceni és dombóvári építési fönökségek alkalmazásában dolgozott a zászlóalj. 1964-ben a zászlóaljak közül egyedüliként kapott megfelelő értékelést a dandárparancsnoktól. A két század mellett 1967-ig az irányítása alá tartozott a 153. zászlóalj 3. százada is, amelyik Kecskeméten, Kiskőrösön és Kisteleken települt a három év alatt. Elöször Kecskeméten települt az 155. zászlóalj törzse, majd 1966 márciusától Kiskunfélegyházán, 1968 januárjától Baján települt az alegység parancsnoksága. 1970-ig a zászlóalj a következő vasútvonalak átépítésében vett részt: Budapest-Cegléd, Cegléd-Szeged, Kiskunhalas-Baja-Dombóvár, ${ }^{133}$ HL MN f. T326/1966. 150. ddr 10/1965 számú parancs. és 5106-5113/79. 153. zlj. 36/1965 számú parancs.

${ }^{134}$ HL MN f. 5102-5105/79. 153. zlj. 1,25,29,44/1964 számú parancs., 5106-5113/79. 67, 72, 100/1965 számú parancsok., 6500-6502/84. 20/1973 számú parancs és Néphadsereg. 1970. jan. 3. 11.

${ }^{135}$ HL MN f. 5115-5121/79. 153. zlj 24, 27, 43, 56, 80/1966 számú parancsok és Vasút. 1967/3. 24., 1968/5. 13., valamint HL MN f. 649-655/81. 153. zlj. 22/1967 számú parancs, 10589-10596/82. 12/1969 számú parancs.

${ }^{136}$ HL MN f. 3424-3430/83. 153. zlj 17, 22, 28/1970 számú parancsok.

${ }^{137}$ MÁV Arch. AE. 12019. d. 8712/1970. Munkaerő biztosítás vonalkorszerüsítéshez, és 9603/1970. Csornai honvédségi század tervbe vett áthelyezésének ügye.

${ }^{138}$ HL MN f. 1097-1106a/84. 153. zlj. 12, 36/1972 számú parancs, 4162-4169/84. 14/1973 számú parancs, 41784184/84. 28, 39, 46, 68/1975 számú parancsok, 4185-4191/84. 56/1976 számú parancs, továbbá 4403-4409/87. 13, 14, 49/1977 számú parancsok; Néphadsereg. 1976. febr. 28. 6. és Vasút. 1973/5. 26-28.

139 Vasút. 1971/10. 27-29.

${ }^{140}$ HL MN f. 3398-3404/83. 155. zlj. 1/1970 számú parancs.

${ }^{141}$ HL MN f. 1575-1579/83. 155. zlj. 1/1972 számú parancs. 
Hatvan-Újszász és Hatvan-Somoskőújfalu, valamint megfordultak a Záhonyi Átrakó Körzet területén és Balatonfenyves környékén is a katonák. 1969-ben háromra, majd egy évvel később négyre bővült a századok száma. ${ }^{142}$

Az 1972-ben megszüntették az alegységet, az alakulat számát a 158. zászlóalj kapta meg, a két zászlóalj személyi állománya „összeolvadt” és ekkor alakult meg az alegység ötödik százada. Ez évtől Monoron települt a törzs, innen irányították a keleti országrészben szétszórt századokat. 1970 és 1977 között a századok tovább dolgoztak a Kiskunhalas-Baja-Dombóvár vonal korszerüsítésén, a Budapest-Debrecen-Záhony vonal átépítésében, illetve a második vágány megépítésében Debrecen-Nyíregyháza és Tiszatenyő-Gyoma szakaszokon. A zászlóalj katonái ugyanakkor jelen voltak a Rákos-Isaszeg, Hatvan-Miskolc-Szerencs-Sátoraljaújhely, Füzesabony-Eger, Kelenföld-Törökbálint és Köbánya-Kispest-Dabas vonal átépítésénél és karbantartási munkáknál, de 1974-ben két szakasszal részt vettek a budapesti MÁV Kórház építkezésén is. ${ }^{143}$

1966. november 15-én alakult meg a 156. vasúti müszaki zászlóalj (MN 1737) négy századdal Salgótarjánban, Gálos Vilmos alezredes parancsnokságával. 1967-es évre megfelelő értékelést kapott a dandárparancsnoktól az alakulat. Az alakulat első évében rögtön nehéz feladatot kapott, az éppen akkor induló Budapest-Vác-Szob vonal átépítésében és a salgótarjáni vonalon dolgozott, de néhány hónapig Martonvásár-Székesfehérvár-Siófok szakaszon is dolgoztak a katonák. Vác-Alsóváros megállóhely közelében a MÁV Magasépítési Főnöksége épített a zászlóalj részére három kétemeletes épületet. ${ }^{144}$ Maga az alegység csak a MÁV Budapesti Építési Főnökség és a Hídépítési Főnökség munkahelyein dolgozott. 1969-ben leadott egy századot az éppen akkor alakuló 158. zászlóalj számára. Ez év végén a zászlóaljnál uralkodó botrányok és helytelen gazdálkodás miatt végül leváltották Gálos alezredest decemberben, a zászlóalj még mindig gazdaságtalanul müködött, míg a többi alegység már önfenntartóvá vált. Új zászlóaljparancsnoknak Gyarmati András alezredest nevezték ki. ${ }^{145}$ 1969-1970-ben egy század dolgozott a Székesfehérvár-Komárom vonal átépítésén, a többi század a szobi fővonalon került alkalmazásra, 1971-től mindegyik század itt dolgozott. ${ }^{146}$

1972-ben két új század került megszervezésre, egy-egy század települt Kelenföldön, Salgótarjánban és Kisbéren, a másik két század Vácon maradt. A kelenföldi század júliusban Győrbe települt át a 154. zászlóalj alárendeltségébe, a Hegyeshalom-Rajka vonal és a rajkai határállomás átépítésén biztosították a munkaerőt. A salgótarjáni század még júniusban Pécel állomáson felállított laktanya kocsikba költözött, hogy a Budapest-Gödöllő szakasz felépítménycseréjén dolgozzanak. Részt vettek még a győri fővonal Budapest-Tatabánya szakaszának átépítésében

${ }^{142}$ HL MN f. 6522-6527/80. 155. zlj 16, 20, 56, 60/1966 számú parancsok, 245-249/81. 20, 32, 44/1967 számú parancsok, 5387-5390/82. 22, 28, 42/1968 számú parancsok, 5391-5396/82. 7, 13, 29, 57, 67/1969 számú parancsok, 5391-5396/82. 1, 24, 45/1970 számú parancsok; Vasút. 1969/4. 30-31.; Néphadsereg. 1965. febr. 27. 10., 1971. aug. 8. 6 .

${ }^{143}$ HL MN f. 153-155/80. 150. ddr. 6, 9, 10, 33/1965 számú parancsok, 1575-1579/83. 155. zlj. 32/1972 számú parancs, 3734-3740/84. 11/1973 számú parancs, 3741-3748/84. 9, 72/1974 számú parancsok, 3749-3756/84. 11, 43, 70/1975 számú parancsok, 3757-3766/84. 31, 37, 99/1976 számú parancsok, 4414-4422/87. 25, 39/1977 számú parancsok. Néphadsereg. 1971. júl. 8. 6., 1975. jan. 4. 8-9., 1976. febr. 28. 6., valamint Vasút. 1971/11. 12.

144 Vasút. 1967/3. 24.

${ }^{145}$ HL MN f. 1556-1562/83. 150. ddr. 65/1969 számú parancs.

${ }^{146}$ HL MN. f. 5929-5937/80. 156. zlj. 12, 33, 62/1967 számú parancsok, 975-982/84. 6, 23, 46, 49, 62, 67, 90/1969 számú parancsok, 9757-9769/84. 90/1971 számú parancs és Néphadsereg. 1970. aug. 1. 7., 1976. júl. 10. 7. 
is. Az Angyalföld-Rákosrendező szakasz és Székesfehérvár-Komárom vonal felépítménycseréje is a zászlóaljhoz köthető. 1974 augusztus-szeptember folyamán a zászlóaljtörzs a 2., 3. és 5. századdal együtt Bicskére települt át, hogy részt vegyen a hegyeshalmi fővonal Kelenföld-Tatabánya szakaszának új nyomvonal történő megépítésében. 1975-ben egy század kivételével a zászlóalj katonái Bicskén települtek, innen jártak Bicske és Herceghalom állomások környékére hídépítési, magasépítési feladatok és felépítménycsere végrehajtására. A következő évben is csak az 1. század nem dolgozott a győri fővonalon, ismét a Rákos-Gödöllő szakaszon és Rákosrendezőn végzett korszerüsítési munkákat. Mivel 1976 őszén befejeződött a győri fővonal átépítésének első üteme, 1977-től a 2., 3. és 5. század Budaörstől egészen Ácsig vállalt munkákat. Az 1. század a váci és veresegyházi vonalon végzett felépítménycserét, illetve a Rákos-Hatvan szakaszon végzett kisebb pályakorszerüsítést, míg a 4. század Budapesten a MÁV Kórház és a Fehérvári úti lakótelep építésén dolgozott. ${ }^{147}$

1969 elején állították fel a 158. vasúti müszaki zászlóaljat (MN 8381) a 153. és 156. zászlóaljaktól átvett egy-egy századdal pilis és salgótarjáni településsel, április folyamán egy nagykátai és egy füzesabonyi elhelyezésű század is megszervezésre került. Az alegység parancsnoka végig Molnár László alezredes volt, majd a már említett összeolvadás után ő vette át a 155. zászlóalj irányítását is. Sajnos csak az 1969 és 1970. évi szolgálati használatú parancsok maradtak fenn az alakulat iratai közül, így itt is a dandár és más alegységek irataira kellett támaszkodnom. A pilisi alegység még alakulásának évében rövid időre Záhonyba lett vezényelve átrakási munkák felgyorsítására. 1970-ben részt vett az alegység is a tiszai árvíz utáni csengeri újjáépítési programban, valamint ebben az évben egy közúti század is felállításra került, ami a 4-es foút korszerüsítésében vett részt Törökszentmiklóson települve. ${ }^{148}$ Rövid fennállása alatt az alábbi munkák köthetők a zászlóaljhoz: második vágány építése Sülysáp és Nagykáta között, Salgótarján-külső pályaudvar átépítési munkáinak befejezése, Nyékládháza-Miskolc és a ceglédi fővonalon Monor-Budai út szakasz felépítményének átépítése. 1970-ben már hat százada volt, öt vasútépítő és egy útépítő. ${ }^{149}$

Összegezve a dandár 1964 és 1980 közötti teljesítményét és nagyobb építkezéseken való részvételét, a következő főbb számokat kapjuk. $756 \mathrm{~km}$ közút építésében vettek részt, amiből 267 km volt autópálya. Jelentős szerepet vállaltak az 1, 3, 4, és 7 számú főutak korszerüsítésében is, a fővárosban pedig a Jászberényi úti, Árpád úti, Sibrik úti, Könyves Kálmán körúti, Flórián téri, Baross téri és Váci úti felüljárok építésénél lehetett látni dolgozó honvédeket, de ott voltak a BAH és MOH csomópontok építésénél, a Millenniumi Földalatti Vasút meghosszabbításán és a két metróépítkezésen is. Mindezek mellett 143 közúti mütárgy építésében vettek részt.

1650 km sínpárt és 621 kitérőt építettek vagy korszerüsítettek a dandár alegységei, ezen kívül 97 vasútállomás (át)építésében vettek részt. A vasútépítő zászlóaljak nélkül nem sikerülhetett volna a fővonalak korszerüsítése, a vasúti hálózat kapacitásának bővítése. A nagyobb vasútállomások közül a budapesti Keleti, Déli és Nyugati pályaudvarok, a kelenföldi, győri

${ }^{147}$ HL MN f. 11373-11384/84. 156. zlj. 27, 56, 67/1972 számú parancsok, 11385-11395/84. 25, 29, 47, 69, 117/1973 számú parancsok, 873-887/85. 38/1974 számú parancs, 888-899/85. 30, 82, 96, 149/1975 számú parancsok, 900912/85. 48, 146/1976 számú parancsok, 4427-4442/87. 45, 56, 76, 101/1977 számú parancsok. Néphadsereg. 1973. jún. 23. 7., 1973. júl. 14. 6., 1974. ápr. 27. 8., 1976. júl. 10. 7., illetve Vasút. 1971/12. 30.

${ }^{148}$ HL MN f. 1563-1565/83. 158. zlj. 18/1969 számú parancs, 1566-1568/83.158. zlj. 23/1970 számú parancs.

${ }^{149}$ HL MN f. 1556-1562/83. 150. ddr. 10, 70/1969 számú parancsok. 5834-5838/83. 1/1970 számú parancs, 860866/84. 45/1971 számú parancs, 4050-4057/84. 22/1972 számú parancs. 
és záhonyi állomások építésében is részt vettek. Posta területén 1596 nyomvonal km hosszú hálózatot fektettek le és megépítették, felújították a hozzátartozó berendezéseket, központokat, postahivatalokat. A vonalépítő alegység az ország teljes területén tevékenykedett, ők fektettek először az országban páncélkábelt. Az építkezések fizikai munkásainak 15\%-át tették ki a katonák a vasúti fővonali pályakorszerüsítéseknél és $40 \%$-át a fővárosi postai kábelfektetésnél. Öszszesen 12892650 munkanapot teljesített és 12,9 millió $\mathrm{m}^{3}$ anyagot mozgatott meg a dandár. ${ }^{150}$ A két dandár 37,8 milliárd forint értéket hozott létre 1964 és 1980 közötti tevékenységével, ebből 13,7 milliárddal részesült a 150. közlekedési dandár. ${ }^{151}$ Országos jelentőségủ feladatok megoldása közben több ezer katona szerzett szakmunkás képesítést, illetve fejezte be általános iskolai tanulmányait.

A közlekedés és hadsereg kapcsolatát vizsgálva meg kell még említeni a nagyobb vasúti balesetek, szerencsétlenségek esetén felhasznált katonai segítségnyújtást. Sokszor közúti és vasúti mentőjárművek részére egyaránt nehezen megközelíthető helyen történtek balesetek, amikor a Magyar Néphadsereg és a Vörös Hadsereg Déli Hadseregcsoportja speciális eszközeivel és gyorsan mozgósítható állományával vett részt a sérültek mentésében és ellátásában, valamint a kárfelszámolásban és helyreállításban. A hatvanas évek legsúlyosabb vasúti baleseteinél, 1964ben Paládicspusztánál és 1968-ban Mendénél is azonnal riasztották a közeli katonai alakulatokat. ${ }^{152}$ Napjainkra a polgári katasztrófa-elháritási rendszer megfelelő felszereltsége már nem igényli egy-egy nagyobb balesetnél a honvédségi erők bevonását a kárfelszámolásba. Persze egy-egy extrém esetben, mint amilyen a 2013 márciusi havazás is volt, még mindig jól jönnek a katonai járművek speciális képességei.

\footnotetext{
${ }^{150}$ Fodor Kálmán. 303. és Halassy-Kürtös. 394-397.

${ }^{151}$ Hargittai. 184. A 160. általános müszaki dandár magasabb termelési értéke annak is köszönhető, hogy ott a zászlóaljak jóval több, esetenként 8-9 századból is álltak, ráadásul az ipari, nehézipari nagyberuházások sokkal komolyabb politikai és gazdasági támogatást élveztek, mint a közlekedésiek.

${ }^{152}$ HL MN Különgyüjtemény. VII/C-6. Koch alezredes: A Magyar Néphadsereg részvétele a súlyosabb vasúti balesetek követelményeinek felszámolásában 1950-től 1980-ig időszakban.
} 


\section{MELLÉKLETEK}

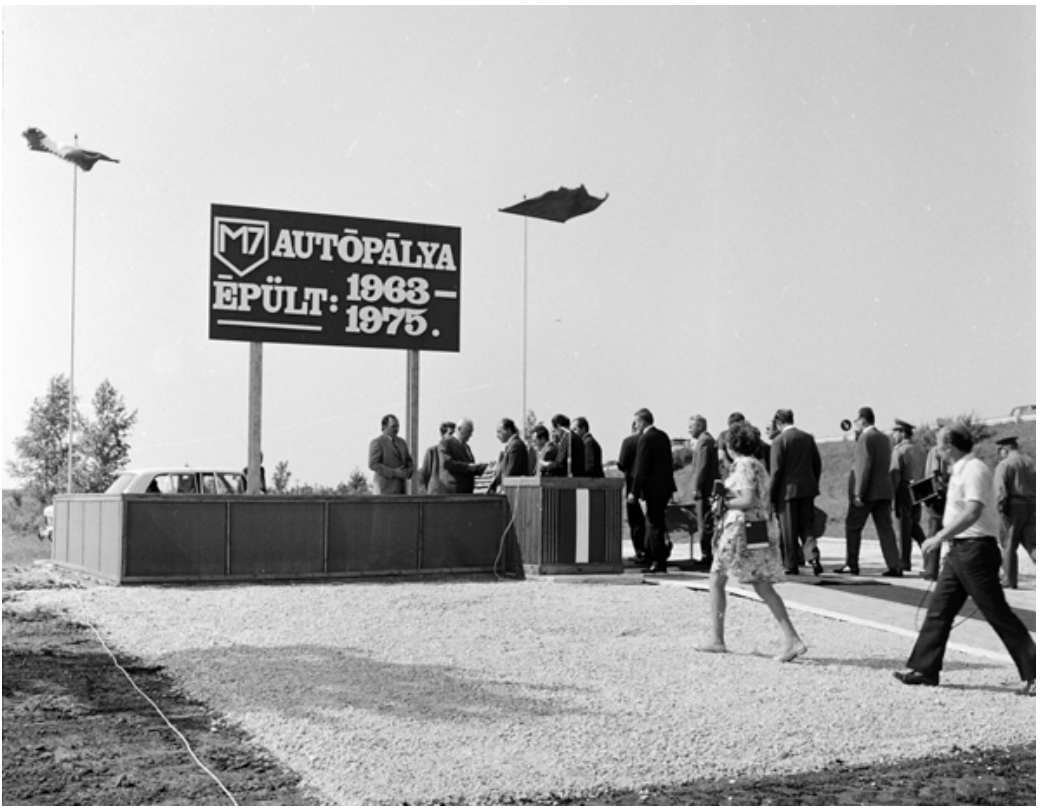

1. kép: M7 autópálya Székesfehérvár-Balatonaliga szakaszának átadása, 1975. Fortepan No. 99378 (UVATERV)

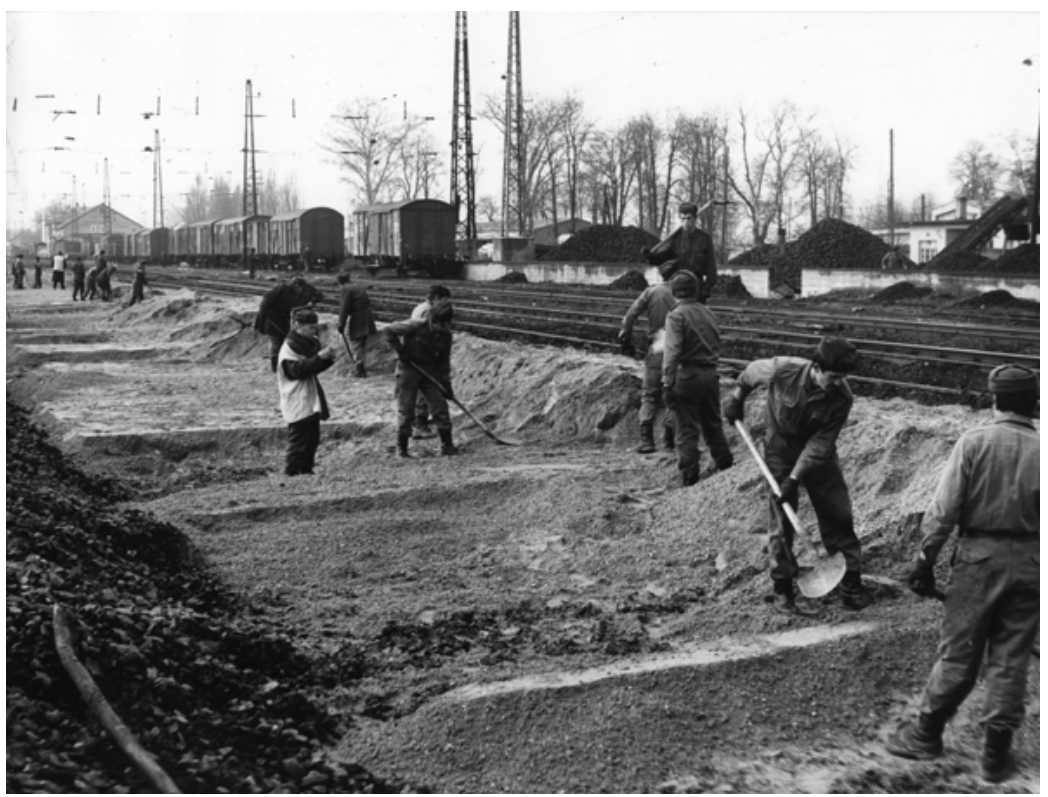

2. kép: Alépítményi tükör készítése közben. MÁV Archívum X20255620. 


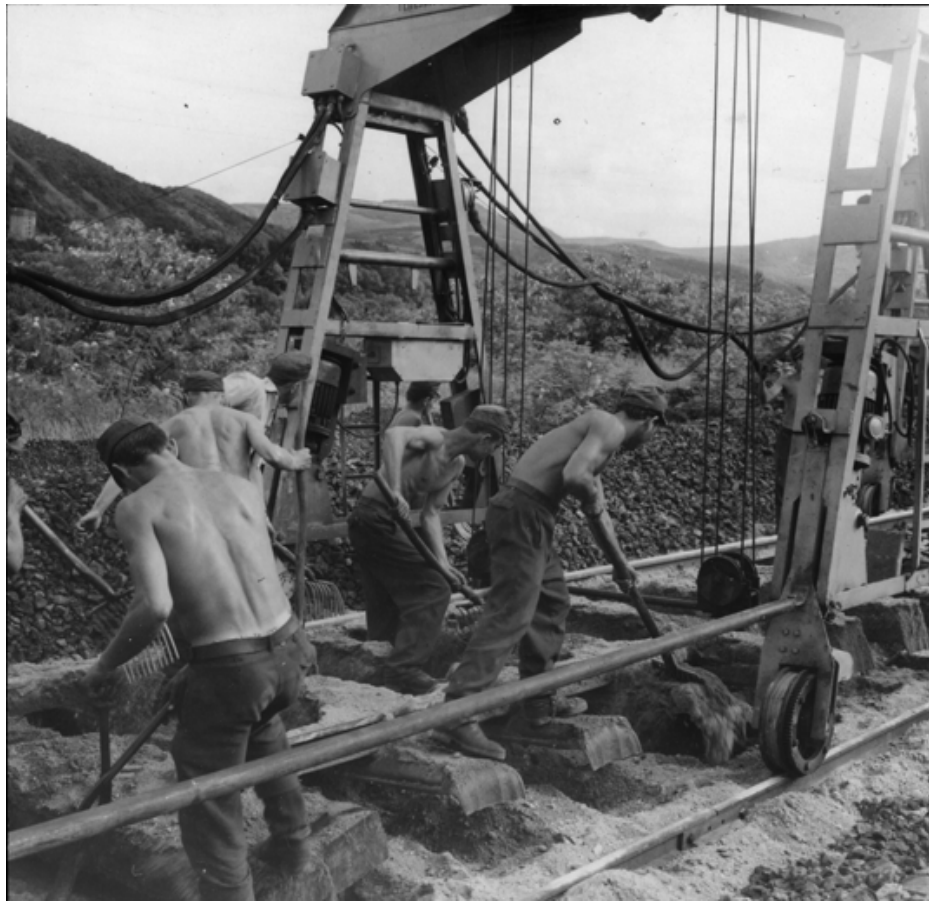

3.kép: Elhasználódott vágányzat bontása portáldaruval, 1971. Érdekesség a Magyarországon kevés helyen alkalmazott vasaljas sínmező. MÁV Archívum X20246478.

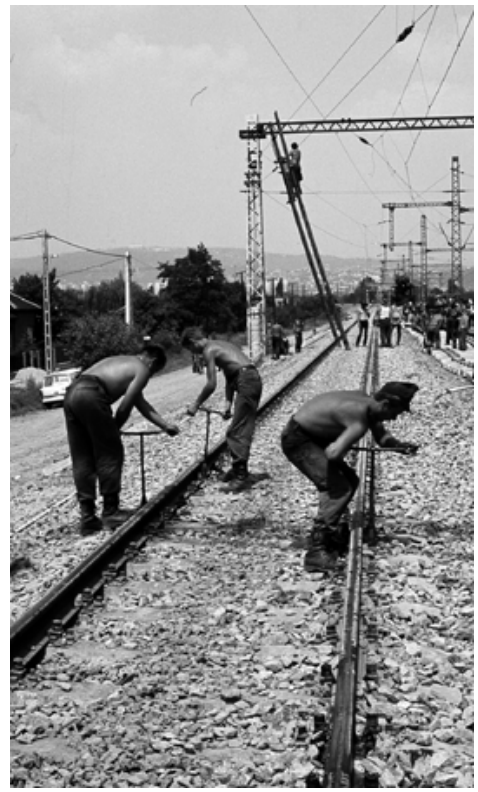

4. kép: Kelenföld pályaudvar rekonstrukciója. Honvédek a leszorító csavarokat húzzák meg Tyrefond kulccsal. MÁV Archívum X20247802. 


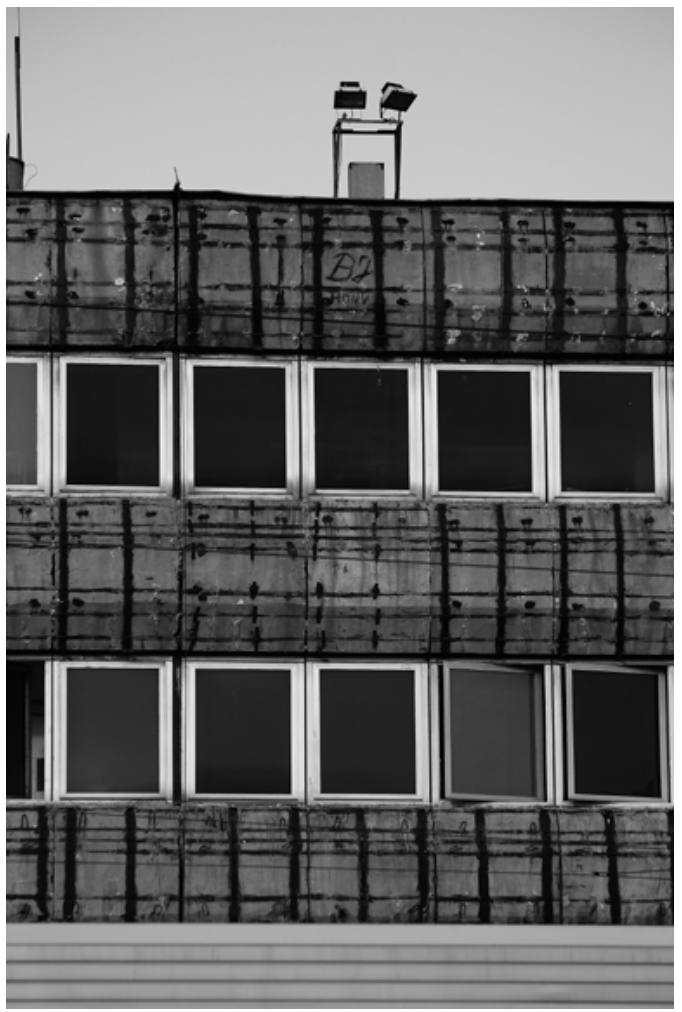

5. kép: B. J. honvéd „aláírása” a Déli pályaudvar 1975-ban elkészült üzemi épület díszburkolata alatt. Szerző

\section{FELHASZNÁLT IRODALOM}

ÁbraHÁm KÁLmán (főszerk.) (1978): A közúti közlekedés kézikönyve. Budapest, Müszaki Könyvkiadó.

AmBrus ZolTÁN (szerk.) (1985): A MÁV épitöipari szervezetének 35 éve, 1950-1985. Budapest, stencil.

BőHm AnTAL (1997): Ingázás tegnap és ma. Budapest, MTA PTI.

Csanádi GyöRgy (1958): A közút és a korszerü közlekedés. Budapest, Akadémia.

FODOR KÁLMÁN (2008): A magyar haderő alaprendeltetésétől eltérő tevékenysége 1945-2006. In Lugosi József - Markó György (szerk.) Hazánk dicsőségére. 160 éves a Magyar Honvédség. Budapest, Zrínyi. 301-311.

FRISNYÁK ZSUZSA (2001): A magyarországi közlekedés krónikája 1750-2000. Budapest, MTA Történettudományi Intézet. 
FRISNYÁK ZsUZSA (2013): A kisforgalmú vasútvonalak bezárása a Kádár-korszakban. In Csáki Krisztina (szerk.) Magyar Müszaki és Közlekedési Múzeum II. évkönyve. Budapest, MMKM. 95-109.

Helgert Imre - Vass Jenő Sándor (szerk.) (2006): A Hazáért, a Magyar Honvédség múltja és jelene 1848-2004. Budapest, Szaktudás.

HoRváTH FERENC (2005): A magyar vasút épitési és fenntartási szervezetének története (18272004). II. kötet (1945-2004). Budapest, MÁV.

Kis TAMÁs (1992): Bakaduma. A mai magyar katonai szleng szótára. Budapest, Zrínyi.

Statisztikai évkönyv. 1966, 1971, 1981. Budapest, KSH.

Máthé Zoltán - Mucsi Barnabás - Nagy TAmás - Vörös Attila (2007): Magyarország mozdonyai. Budapest, Indóház.

Major IváN (1984): Közlekedés és gazdaság. Budapest, Magvető.

Mezei István (2009) (szerk.): A magyar vasút krónikája a XX. században. Budapest, MÁV.

Nemesdy ERvin (1996) (föszerk.): A magyar autópályák története. Az elsö 35 év. Budapest, KHVM Autópálya Igazgatóság.

SzANi FERENC (1999): Néphadsereg 1957-1989. Budapest, Honvéd.

UNYI BÉLA (1989): Vasúthálózatunk alakulása 1914-től napjainkig. Budapest, KÖZDOK.

VAluch Tibor (2005): Magyarország társadalomtörténete a XX. század második felében. Budapest, Osiris.

VASS Henrik (1968): A Magyar Szocialista Munkáspárt határozatai és dokumentumai 19631966. Budapest, Kossuth.

A közlekedés hosszútávú terve 1971-1985 (1970). Budapest, KÖZDOK.

\section{LEVÉLTÁRI FORRÁSOK}

Hadtörténelmi Levéltár

MN fond (mikrofilm)

MN Különgyüjtemény

MÁV Archívum

AC fond: MÁV Szegedi igazgatóság iktatott iratok

AE fond: MÁV Szombathelyi igazgatóság iktatott iratok

AG fond: MÁV Pécsi igazgatóság iktatott iratok

LV fond: MÁV Vezérigazgatóság iktatott iratok (MNL OL-nek átadva) 
Magyar Nemzeti Levéltár Országos Levéltára

M-KS 288 fond: Magyar Szocialista Munkáspárt iratai

XIX-H-1-c fond: Közlekedés- és Postaügyi Minisztérium visszaminősített TÜK iratok

XIX-H-1-pp fond: Közlekedés- és Postaügyi Minisztérium iktatott iratok

\section{SAJTó}

Autó-Motor

Haditechnikai Szemle

Magyar Ifjúság

Néphadsereg

Népszabadság

Vasút 